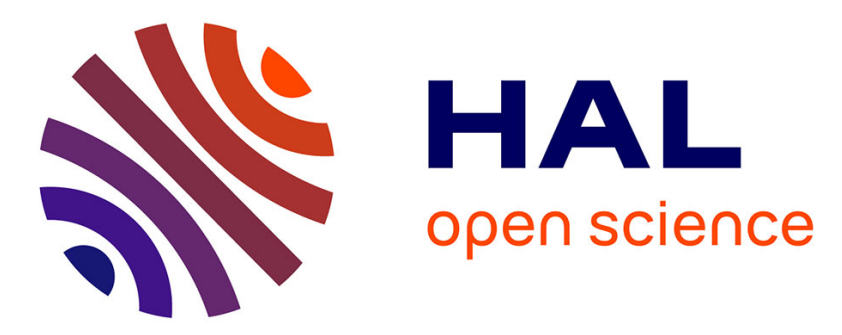

\title{
East Germanic and Alano-Sarmatian Finds of the Early Migration Period in the Roman West.
}

\author{
Michel Kazanski, Aleksander Bursche, John Hines, Anna Zapolska
}

\section{To cite this version:}

Michel Kazanski, Aleksander Bursche, John Hines, Anna Zapolska. East Germanic and AlanoSarmatian Finds of the Early Migration Period in the Roman West.. The Migration Period between the Oder and the Vistula, 59, Brill, pp.830-852, 2020, East Central and Eastern Europe in the Middle Ages, 450-1450, 978-90-04-42273-5. 10.1163/9789004422421_027. hal-02902011

\section{HAL Id: hal-02902011 \\ https://hal.science/hal-02902011}

Submitted on 24 Jul 2020

HAL is a multi-disciplinary open access archive for the deposit and dissemination of scientific research documents, whether they are published or not. The documents may come from teaching and research institutions in France or abroad, or from public or private research centers.
L'archive ouverte pluridisciplinaire HAL, est destinée au dépôt et à la diffusion de documents scientifiques de niveau recherche, publiés ou non, émanant des établissements d'enseignement et de recherche français ou étrangers, des laboratoires publics ou privés. 


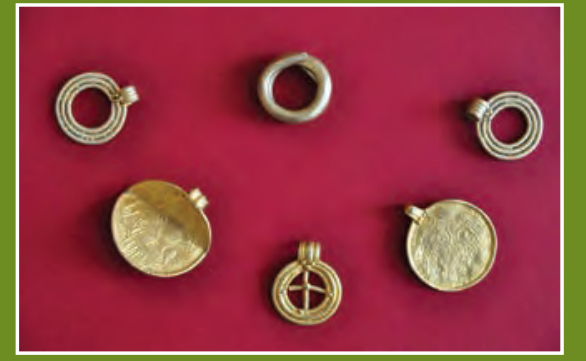

Prof. Aleksander Bursche

coordinated the Migration Period between the Oder and the Vistula between the Oder and the Vistuld
project, the results of which are project, the results of which are
published here. He is a full professor published here. He is a full profe
at the University of Warsaw at the University of Warsaw specialising in relations between the
Classical World and the Barbarians.

Prof. John Hines is Professor in the School of History, Archaeology and Religious Studies, Cardiff University. He has published extensively on material and literary culture, and linguistic history, in northern Europe from the Late Iron Age to the Modern Period.

Dr. Anna Zapolska is a researcher in the Institute of Archaeology, Warsaw University. She specialises in numismatics, coin finds, and coin in archaeological contexts. She is currently working on the bronze
coin finds from sites of the West Balt Cultures.
This collection of studies is the result of a six-year interdisciplinary research project undertaken by an international team of archaeologists, historians, numismatists and paleobotanists. It constitutes a completely new approach to environmental, cultural and settlement changes during the Migration Period in Central Europe.

Part One discusses written sources, theories regarding migration, and environmental change in the first millennium AD. In Part Two, archaeological sources relating to Central Europe in the Migration Period are analysed, while Part Three is devoted to new discoveries between the Oder and the Vistula, including traces of Germanic settlement in northern Poland in the early seventh century. In Part Four, evidence for cultural and settlement changes in neighbouring areas is characterized in a comparative light.
The Migration Period between the Oder and the Vistula

Volume 1

(a)

Edited by

Aleksander Bursche, John Hines and Anna Zapolska

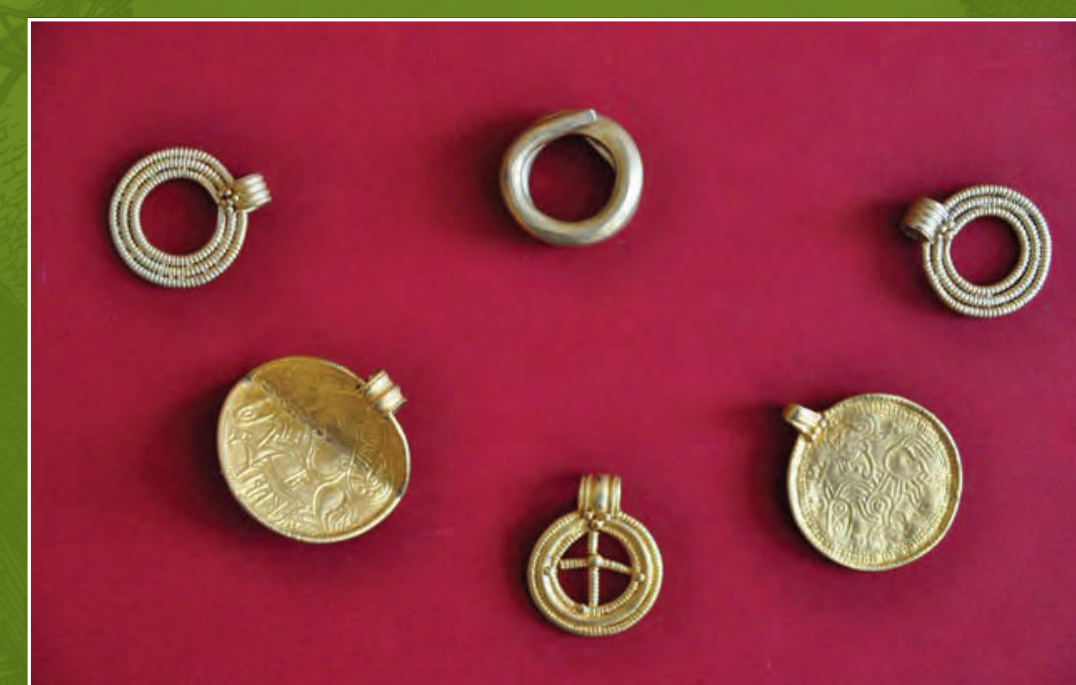

B RILL 


\title{
East Central and Eastern Europe in the Middle Ages, 450-1450
}

\author{
General Editors \\ Florin Curta and Dušan Zupka
}

VOLUME $59 / 2$ 


\title{
The Migration Period between the Oder and the Vistula
}

\author{
Volume 2
}

\author{
Edited by
}

Aleksander Bursche

John Hines

Anna Zapolska

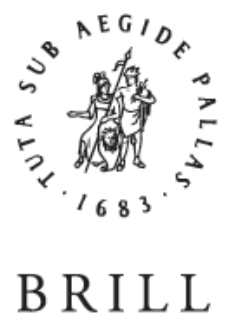


This publication was prepared within the project "Migration Period between the Odra and the Vistula" financed from the resources of the National Science Centre in Poland awarded basing on decision no. DEC-2011/02/A/HS3/oo389.
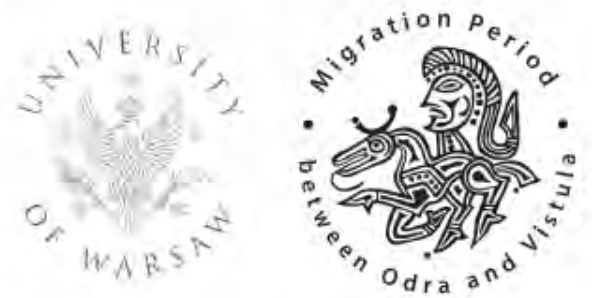

Cover illustration: hoard from Suchań, site 18 in West Pomerania.

The Library of Congress Cataloging-in-Publication Data is available online at http://catalog.loc.gov LC record available at http://lccn.loc.gov/2019058066

Typeface for the Latin, Greek, and Cyrillic scripts: "Brill". See and download: brill.com/brill-typeface.

ISSN 1872-8103

ISBN 978-90-04-42240-7 (hardback)

ISBN 978-90-04-42272-8 (volume 1)

ISBN 978-90-04-42273-5 (volume 2)

ISBN 978-90-04-42242-1 (e-book)

Copyright 2020 by Koninklijke Brill NV, Leiden, The Netherlands.

Koninklijke Brill NV incorporates the imprints Brill, Brill Hes \& De Graaf, Brill Nijhoff, Brill Rodopi, Brill Sense, Hotei Publishing, mentis Verlag, Verlag Ferdinand Schöningh and Wilhelm Fink Verlag. All rights reserved. No part of this publication may be reproduced, translated, stored in a retrieval system, or transmitted in any form or by any means, electronic, mechanical, photocopying, recording or otherwise, without prior written permission from the publisher.

Authorization to photocopy items for internal or personal use is granted by Koninklijke Brill NV provided that the appropriate fees are paid directly to The Copyright Clearance Center, 222 Rosewood Drive, Suite 910, Danvers, MA 01923, USA. Fees are subject to change.

This book is printed on acid-free paper and produced in a sustainable manner. 


\section{Contents}

List of Figures, Maps, Diagrams and Tables IX Abbreviations XXXIX

\section{VOLUME 1}

Introduction 1

Aleksander Bursche

\section{PART 1}

History, Theory and Environment

1 Migration Studies in Archaeology: Building a Circumstantial Case 15 Marzena J. Przybyta

$2 \quad$ Migration and Identity in Late Antiquity 65 Peter Heather

3 The Migration Period in Poland in the Light of Literary Sources 84 Marcin Wotoszyn

4 Pollen Evidence of Change in Environment and Settlement during the 1st Millennium AD 137

Anna Pędziszewska, Małgorzata Latałowa, Joanna Święta-Musznicka, Marcelina Zimny, Mirosława Kupryjanowicz, Agnieszka Noryśkiewicz and Karolina Bloom

\section{PART 2}

Between the Oder and the Vistula

5 The Chronology 201

Magdalena Mączyńska

6 Styles 225

Anna Bitner-Wróblewska, Alexandra Pesch and Marzena J. Przybyła 
$7 \quad$ Settlements 299

Henryk Machajewski

8 Cemeteries and Burials 333

Henryk Machajewski and Jan Schuster

9 Early Migration Period Nomadic Finds 370

Judyta Rodzińska-Nowak

10 Shared Divine Imagery: Gold Bracteates 411

Alexandra Pesch

$11 \quad$ The Southern Baltic Region 434

Magdalena Maczyńska

12 Southern and Central Poland 451

Magdalena Mączyńska

VOLUME 2

PART 3

\section{Case Studies}

13 Kujawy (Central Poland) between Antiquity and Middle Ages 469 Marcin Rudnicki and Mirostaw Rudnicki

14 Roman Origin and Migration Period Military Equipment from Kujawy 500 Bartosz Kontny and Marcin Rudnicki

15 The Hoard from Łubiana in Pomerania 539 Magdalena Mączyńska

16 The Hoard of Solidi from Karsibór in Western Pomerania 542 Anna Zapolska

17 The Gold Hoard from Suchań in Western Pomerania and Its Context 566

Aleksander Bursche and Barttomiej Rogalski 
18 New Evidence for the Migration Period in the Central Prosna Basin 592 Stawomir Mitek

\section{PART 4}

\section{Beyond the Oder and the Vistula}

19 Southern Scandinavia in the Migration Period - an Overview 627 Andreas Rau

20 The Making of the Vidivarii: Germanic and Baltic Interculturation in the Late 5 th Century 649 Bartosz Kontny

$21 \quad$ The Balt Neighbours - the Olsztyn Group 689 Anna Bitner Wróblewska

Migration-Period Culture and Changes in the East European Forest-Steppe Zone 731 Michail Lyubichev and Kyrylo Myzgin

23 Who Were the Gepids and Ostrogoths on the Middle Danube in the 5th Century? An Archaeological Perspective 771 Zsófia Rácz

24 Between the Rhine, the Danube and the Oder from the $5^{\text {th }}$ to the End of the 7 th Century: a Sketch 790 Michael Schmauder and Jan Schuster

25 East Germanic and Alano-Sarmatian Finds of the Early Migration Period in the Roman West 830

Michel Kazanski

26 The Migration Period between the Oder and the Vistula: an Outline 853 Aleksander Bursche, Matgorzata Latałowa and Magdalena Maczyńska

Afterword 877

Aleksander Bursche and Magdalena Mączyńska

Bibliography 881

Geographical Index 1033 


\section{Abbreviations}

AAC

AAHung.

Acta Palaeobot.

Alamannen

Altertumskunde

Am. Ant.

Am. Antr.

An. Rev. Antr.

APolski

A. Praeh. Arch.

Arch. Balt.

Arch. Ért.

Arch. Korr.

Arch. Lit.

Arch. u. Gesch.

Archeologia

Jaćwieży

Archeologia o

początkach

Archeologiczne

dziedzictwo
Acta Archaeologica Carpathica

Acta Archaeologica Academiae Scientiarum Hungaricae

Acta Palaeobotanica

Die Alamannen, ed. K. Fuchs et al. (Stuttgart: Theiss, 1997).

Altertumskunde - Altertumswissenschaft - Kulturwissenschaft: Erträge und Perspektiven nach 4o Jahren Reallexikon der Germanischen Altertumskunde, ed. H. Beck, D. Guenich, H. Steuer (Berlin / Boston: De Gruyter, 2012).

American Antiquity

American Anthropologist

Annual Review of Anthropology

Archeologia Polski

Acta Praehistorica et Archaeologica

Archaeologia Baltica

Archaeologiai Értesíto"

Archäologisches Korrespondenzblatt

Archaeologia Lituana

Archäologie und Geschichte. Freiburger Forschungen zum ersten Jahrtausend in Südwestdeutschland

Archeologia Jaćwieży. Dawne badania i nowe perspektywy, ed. A. Bitner-Wróblewska, W. Brzeziński, M. Kasprzycka (Warsaw: Państwowe Muzeum Archeologiczne / Stowarzyszenie Starożytników, 2016).

Archeologia o początkach Stowian. Materiaty z konferencji, Kraków, 19-21 listopada 2001, ed. P. Kaczanowski, M. Parczewski (Cracow: Instytut Archeologii UJ, 2005).

Archeologiczne dziedzictwo Prus Wschodnich $w$ archiwum Feliksa Jakobsona / Das archäologische Vermächtnis Ostpreußens im Archiv des Felix Jakobson / Austrumprūsijas arheologiskais mantojums Fēliksa Jākobsona arhīvā, ed. T. Nowakiewicz (Warsaw: Ministerstwo Kultury i Dziedzictwa Narodowego, Departament Dziedzictwa Kulturowego, 2011).

Archeologiczne Archeologiczne księgi inwentarzowe dawnego Prussia-Museum / ksieggi
Die archäologischen Inventarbücher aus dem ehemaligen PrussiaMuseum / Arkheologicheskiye inventarnyye knigi byvshego muzeya «Prussiya», ed. A. Bitner-Wróblewska (Olsztyn: Archiwum Państwowe w Olsztynie, 2008). 
Archaeology of The Archaeology of Gudme and Lundeborg. Papers Presented at a Gudme Conference at Svendborg, October 1991, ed. P.O. Nielsen, K. Randsborg, H. Thrane (Copenhagen: Akademisk Forlag, 1994).

Attila Attila und die Hunen, ed. B. Anke, H. Externbrink (Stuttgart: Theiss, 2007).

Battowie

Battowie i ich sasiedzi. Marian Kaczyński in memoriam, ed. A. BitnerWróblewska, G. Iwanowska (Warsaw: Państwowe Muzeum Archeologiczne, 2009).

Barbaren im Barbaren im Wandel. Beiträge zur Kultur- und Identitätsumbildung Wandel

Barbari superiores in der Völkerwanderungszeit, ed. J. Tejral (Brno: Archeologický Ústav AV ČR Brno, 2007).

Barbari superiores et inferiores. Archeologia barbarzyńców 2014.

Procesy integracji środkowoeuropejskiego Barbaricum. Polska Czechy - Morawy - Stowacja, ed. L. Tyszler, E. Droberjar (Łódź / Wieluń: Muzeum Ziemi Wieluńskiej, 2015).

Barbarian On Barbarian Identity: Critical Approaches to Ethnicity in the Early Identity Barbarians Barbarzyńskie Tsunami Middle Ages, ed. A. Gillett (Turnhout: Brepols, 2002).

Neglected Barbarians, ed. F. Curta (Turnhout: Brepols, 2010). Barbarzyńskie Tsunami - Okres Wędrówek Ludów w dorzeczu Odry $i$ Wisty / Barbarian Tsunami. The Migration Period in Oder and Vistula River Basin, ed. A. Bursche, K. Kowalski, B. Rogalski (Warsaw / Szczecin: Instytut Archeologii UW / Muzeum Narodowe w Szczecinie, 2017).

BerRGK

Bericht der Römisch-Germanischen Kommission

B. St.

Byzantine Coins

\section{Baltische Studien}

Byzantine Coins in Central Europe between the 5th and 1oth Century, ed. M. Wołoszyn (Cracow / Rzeszów: Polish Academy of Arts and Sciences / Institute of Archaeology, University of Rzeszów, 2009).

Central Places Central Places in the Migration and Merovingian Periods. Papers from the 52nd Sachsensymposion Lund, August 2001, ed. B. Hårdh, L. Larsson (Stockholm: Almqvist \& Wiksell, 2002).

Ceramika Ceramika rzemieślnicza jako źródto do badań nad zróżnicowaniem rzemieślnicza garncarstwa kultury przeworskiej, ed. H. Machajewski, B. Jurkiewicz (Gdańsk / Pułtusk: Instytut Archeologii UG / Instytut Antropologii i Archeologii Akademii Humanistycznej im. Aleksandra Gieysztora, 2010).

Ceramika Ceramika warsztatowa $w$ środkowoeuropejskim Barbaricum, ed. A. warsztatowa Błażejewski (Wrocław: Instytut Archeologii UWr., 2008). 
Contacts

Cur. Anth.

Czas przeszły

dokonany ... 2016

DOC

EAZ

Epokha

Merovingov

Evidence

Felix Jakobson

$F M R D$ XI

Fr. St.

Franken

Frühe Slawen

Geografia Polski

Germanen
Contacts across the Baltic Sea during the Late Iron Age (5th-12th centuries). Baltic Sea Conference, Lund, October 25-27, 1991, ed. B. Hårdh, B. Wyszomirska-Werbart (Lund: University of Lund, Institute of Archaeology, 1992).

Current Anthropology

"Czas przeszły dokonany. Bliski Wschód z początku Xx wieku oczami dominikanów. Fotografie z francuskiej szkoły biblijnej i archeologicznej w Jerozolimie." W drodze 6, 2016, 88-101.

A.R. Bellinger, Catalogue of the Byzantine Coins in Dumberton Oaks Collection and the Whittemore Collection, vol. 1: Anastasius I to Maurice 491-6o2 (Washington, DC, 1966).

Ethnographisch-Archäologische Zeitschrift

Epokha Merovingov - Evropa bez granits. Arkheologiya i istoriya V-VIII vv / Merowingerzeit - Europa ohne Grenzen. Archäologie und Geschichte des 5. bis 8. Jahrhunderts / The Merovigian PeriodEurope without Borders. Archaeology and History of the 5th to 8th Centuries, ed. W. Menghin (Berlin: Staatliche Museen zu Berlin / Edition Minerva, 2007).

Evidence of the Roman Army in Slovenia / Sledovi rimske vojske na Slovenskem, ed. J. Istenič, B. Laharnar, J. Horvat (Ljubljana: Narodni muzej Slovenije, 2015).

Felix Jakobson. Die Brandgräberfelder von Daumen und Kellaren im Kreise Allenstein, Ostpr., ed. A. Bitner-Wróblewska, C. von Carnap-Bornheim, J. Ciglis, V. Hilberg, W. Nowakowski (Neumünster: Wachholtz, 2009).

R. Laser, K. Stribrny, Fundmünzen der römischen Zeit in Deutschland. Abt. XI. Brandenburg (Berlin: von Zabern, 1977).

Frühmittelalterliche Studien

Die Franken. Wegbereiter Europas. Vor 1500 Jahren: König Chlodwig und seine Erben. Katalog der Ausstellung im Reiss-Museum Mannheim, 8. September 1996 bis 6. Januar 1997, ed. A. Wieczorek (Mainz: von Zabern, 1996).

Frühe Slawen in Mitteleuropa. Schriften von Kazimierz Godtowski, ed. J. Bemmann, M. Parczewski (Neumünster: Wachholtz, 2005).

Geografia Polski. Środowisko przyrodnicze, ed. L. Starkel (Warsaw: PWN, 1991).

Germanen, Hunnen und Awaren. Schätze der Völkerwanderungszeit, ed. W. Menghin et al. (Nürnberg: Germanisches Nationalmuseum, 1987).

Glaube 
Freeden, H. Friesinger, H. Wamers (Bonn: Habelt, 2009).

Goci i ich sasiedzi Goci i ich sąsiedzi na Pomorzu. Materiaty z konferencji „Goci na Pomorzu Środkowym”, Koszalin 28-29 października 2005, ed. W. Nowakowski et al. (Koszalin: Muzeum w Koszalinie, 2006).

Goldbrakteaten Die Goldbrakteaten der Völkerwanderungszeit - Auswertung und Neufunde, ed. W. Heizmann, M. Axboe (Berlin / New York: De Gruyter, 2011).

Goldsmith Goldsmith Mysteries. Archaeological, Pictorial and Documentary Mysteries Evidence from the First Millennium AD in Northern Europe. Papers Presented at a Workshop Organized by the Centre for Baltic and Scandinavian Archaeology (ZBSA), Schleswig, April 2oth and 21st, 2011, ed. A. Pesch, R. Blankenfeldt (Neumünster: Wachholtz, 2012).

Greek and Roman Greek and Roman Historiography in Late Antiquity: Fourth to Sixth Century A.D., ed. G. Marasco (Leiden / Boston: Brill, 2003).

Honoratissimum Honoratissimum assensus genus est armis laudare. Studia dedyassensus kowane Profesorowi Piotrowi Kaczanowskiemu z okazji siedemdziesiątej rocznicy urodzin, ed. R. Madyda-Legutko, J. Rodzińska-Nowak (Cracow: Historia Iagellonica, 2014).

Horse and Man The Horse and Man in European Antiquity (Worldview, Burial Rites, and Military and Everyday Life), ed. A. Bliujienė (Klaipėda: Klaipėda University Press, 2009).

Hunnen und Hunnen und Awaren. Reitervölker aus dem Osten, Burgenländische Awaren Landesausstellung 1996, Schloss Halbturn, 26. April - 31. Oktober 1996: Begleitbuch und Katalog, ed. F. Daim (Eisenstadt: Amt der Burgenländischen Landesregierung, 1996).

Hunok Hunok - Gepidák - Langobardok, ed. I. Bóna et al. (Szeged: JATE Magyar Őstörténeti Kutatócsoport, 1993).

IK (Ikonographisches Katalog 1985-1989); K. Hauck et al., Die Goldbrakteaten der Völkerwanderungszeit. Ikonographischer Katalog, Kammergräber - Kammergräber im Barbaricum. Zu Einflüssen und Übergangsphänomenen von der vorrömischen Eisenzeit bis in die Völkerwanderungszeit, ed. A. Abegg-Wigg, N. Lau (Neumünster / Hamburg: Wachholtz, 2014).

Inter Ambo Inter Ambo Maria. Contacts between Scandinavia and the Crimea in Maria 1 the Roman Period, ed. I. Khrapunov, F.A. Stylegar (Kristiansand / Simferopol': Dolya Publishing House, 2011).

Inter Ambo Inter Ambo Maria. Contacts between Scandinavia and the Crimea in Maria 2 the Roman Period, ed. I. Khrapunov, F.A. Stylegar (Kristiansand / Simferopol': Dolya Publishing House, 2013). 
J. Bod. Meck.-Vrp. Jahrbuch Bodendenkmalpflege in Mecklenburg-Vorpommern

J. Paleolimnol.

JRGZM

Jrn. Ant. Arch.

Jrn. Arch. Sc.

Keszthely-

Fenékpuszta

Kom. $M-W$

Kultura

bogaczewska
Journal of Paleolimnology

Jahrbuch des Römisch-Germanischen Zentralmuseums Mainz

Journal of Anthropological Archaeology

Journal of Archaeological Science

Keszthely-Fenékpuszta im Kontext spätantiker Kontinuitätsforschung zwischen Noricum und Moesia, ed. O. Heinrich-Tamáska (Rahden/Westf.: Leidorf, 2011).

Komunikaty Mazursko-Warmińskie

Kultura bogaczewska w 20 lat później. Materiaty z konferencji, Warszawa, 26-27 marca 2003, ed. A. Bitner-Wróblewska (Warsaw: Państwowe Muzeum Archeologiczne / Stowarzyszenie Naukowe Archeologów Polskich, 2007).

Kultura przeworska Kultura przeworska. Odkrycia - interpretacje - hipotezy, vol. 1, ed. M. Olędzki, J. Skowron (Łódź: Multikram, 2004).

Kultura wielbarska 1

Kultura

wielbarska 2 Kultura wielbarska w mtodszym okresie rzymskim, vol. 1, ed. J. Gurba, A. Kokowski (Lublin: UMCs, 1988).

Kultura wielbarska $w$ mtodszym okresie rzymskim, vol. 2, ed. J. Gurba, A. Kokowski (Lublin: u Mcs, 1989).

Kulturwandel

Kurze

Fundberichte

LAA 1977

Liet. Arch.

L'Occident romain

Macht des Goldes

Kulturwandel in Mitteleuropa. Langobarden - Awaren - Slawen. Akten der Internationaler Tagung in Bonn, vom 25. bis 28. Februar 2008, ed. J. Bemmann, M. Schmauder (Bonn: Habelt, 2008).

"Kurze Fundberichte." In Jahrbuch Bodendenkmalpflege in Mecklenburg (Vorpommern), various years and volumes.

Lietuvos Archeologijos Altasas III. I-XIII a. pilkapynai ir senkapiai, (Vilnius, 1977).

Lietuvos Archeologija

L'Occident romain et l'Europe centrale au debut de l'époque des Grandes Migrations, ed. J. Tejral, Ch. Pillet, M. Kazanski (Brno: Archeologický Ústav AV ČR Brno, 1999).

Macht des Goldes, Gold der Macht. Herrschafts- und Jenseitsrepräsentation zwischen Antike und Frühmittelalter im mittleren Donauraum. Akten des 23. Internationalen Symposiums der Grundprobleme der frühgeschichtlicher Entwicklung im mittleren Donauraum, Tengelic, 16.-19.11.2011, ed. M. Hardt, O. HeinrichTamáska (Weinstadt: Greiner, 2013).

Mat. Ark. Ist. Etn. T. Materialy po Arkheologii, Istorii i Etnografii Tavrii

Mat. Star.

Materiaty Starożytne 
Mortuary Practices

N. Num.

Na hranicích

impéria

Natural

Catastrophes

Nowe materiaty

Orbis Barbarorum

Ostrogothica

PArch.

Photographisches Album

PNAS USA

Pogranicze

Pontic-Danubian

Realm

Prahistoria
Mortuary Practices and Social Identities in the Middle Ages. Essays in Burial Archaeology in Honour of Heinrich Härke, ed. D. Sayer, H. Williams (Exeter: University of Exeter Press, 2009).

Notae Numismaticae

Na hranicích impéria - Extra Fines Imperii. Jaroslavu Tejralovik8o. Narozeninám, ed. Z. Měřínský, H. Sedláčková (Brno: Masarykova Univerzita / Archeologický Ústav Akademie Věd ČR, 2017).

Natural Catastrophes During Bronze Age Civilisations.

Archaeological, Geological, Astronomical and Cultural Perspectives, ed. B.J. Peiser, T. Palmer, M.E. Bailey (Oxford: BAR Publishing, 1998).

Nowe materiaty i interpretacje. Stan dyskusji na temat kultury wielbarskiej, ed. M. Fudziński, H. Paner (Gdańsk: Muzeum Archeologiczne w Gdańsku, 2007).

Orbis Barbarorum. Studia ad archaeologiam Germanorum et Baltorum temporibus Imperii Romani pertinentia Adalberto Nowakowski dedicata, ed. J. Andrzejowski, et al. (Warsaw / Schleswig: Instytut Archeologii UW / Zentrum für Baltische und Skandinavische Archäologie, 2017).

Ostrogothica. Archäologie des Zentral- und Osteuropas in der Späten Römischen Kaiserzeit und der Völkerwanderungszeit, ed. K. Myzgin (Kharkiv: Timčenko, 2009).

Przeglad Archeologiczny

Photographisches Album der Prähistorischen und Anthropologischen Ausstellung zu Berlin 188o, vol. 2 (Berlin: C. Berg \& v. Holten, 1880).

Proceedings of the National Academy of Sciences of the United States of America

Pogranicze trzech światów. Mazowsze u schytku starożytności, ed. A. Jarzec, trzech światów W. Nowakowski, A. Szela (Warsaw: Instytut Archeologii UW, 2006). The Pontic-Danubian Realm in the Period of the Great Migration, ed. V. Ivanišević, M. Kazanski (Paris / Belgrade: Association des amis du Centre d'histoire et civilisation de Byzance / Arheološki institut Beograd, 2012). Prahistoria ziem polskich, vol. 5: Późny okres lateński i okres rzymski, ed. J. Wielowiejski (Wrocław: Zakład Narodowy im. Ossolińskich, 1981). 
Problem der

Deutung

Probleme

Prussia

Quaternary Res.

$R B$

Rev. Palaeobot. Palyno.

$R G A$

RIC

Rom und die

Barbaren

Roman Gold

Romania Gothica

Runeninschriften

$S A$

Samfundsorganisation

Sieg und Triumpf

Sîntana de Mureş

Stowianie
Zum Problem der Deutung frühmittelalterlicher Bildinhalte. Akten des 1. Internationalen Kolloquiums in Marburg a. d. Lahn, ed. H. Roth (Sigmaringen: Thorbecke, 1986).

Probleme der relativen und absoluten Chronologie ab Latenèzeit bis zum Frühmittelalter, ed. K. Godłowski, R. MadydaLegutko (Cracow: Instytut Archeologii UJ, 1992).

Sitzungsberichte der Altertumsgesellschaft Prussia

Quaternary Research

Rocznik Biatostocki

Review of Palaeobotany and Palynolology

Reallexikon der Germanischen Altertumskunde

Roman Imperial Coinage, J. Kent (ed.), vol. 10 (London, 1994).

Rom und die Barbaren. Europa der Zeit der Völkerwanderung, 22. August bis 7. Dezember 2008 in der Kunst- und Ausstellungshalle der Bundesrepublik Deutschland, Bonn, ed. J. Bemmann (Munich: Hirmer, 2008).

Roman Gold and the Development of Early Germanic Kingdoms, ed. B. Magnus (Stockholm: Kungl. Vitterhets Historie och Antikvitets Akademien, 2001).

Romania Gothica II. The Frontier World, Romans, Barbarians and Military Culture, ed. T. Vida (Budapest: Eötvös Loránd University / Martin Opitz Kiadó, 2015).

Runeninschriften als Quellen interdisziplinärer Forschung. Abhandlungen des Vierten Internationalen Symposiums über Runen und Runeninschriften in Göttingen vom 4.-9. August 1995, ed. K. Düwel, S. Nowak (Berlin / New York: De Gruyter, 1998).

Silesia Antiqua

Samfundsorganisation og Regional Variation. Norden iromersk jernalder og folkevandringstid. Beretning fra 1. Nordiske jernaldersymposium på Sandbjerg Slot 11.-15. April 1989, ed. Ch. Fabech, J. Ringtved (Aarhus: Universitetsforlag, 1991).

Sieg und Triumpf. Der Norden im Schatten des Römischen Reiches / The Spoils of Victory. The North in the Shadow of the Roman Empire, ed. L. Jørgensen et al. (Copenhagen: Nationalmuseet, 2003).

Die Sîntana de Mureş-Černjachov-Kultur, ed. G. GomolkaFuchs (Bonn: Habelt, 1999).

Stowianie $i$ ich sasiedzi we wczesnym średniowieczu, ed. M. Dulinicz (Warsaw / Lublin: UMCS, 2003). 
Sorte Muld

Sov. Ark.

Spätrömische

Kaiserzeit

SprArch.

St. Sfrsch.

Superiores Barbari

Terra Barbarica

Treasures of Suchań

Turbulent Epoch

Ubitribus

Völker an der Donau

Vostochnaya Evropa

WA

Völker
Sösdala Horsemen

Sorte Muld: Wealth, Power and Religion at an Iron Age Central Settlement on Bornholm, ed. U. Adamsen, F.O. Nielsen, M. Watt (Rønne: Bornholms Museum, 2009).

The Sösdala Horsemen and the Equestrian Elite of Fifth Century Europe, ed. Ch. Fabech, U. Näsman (Moesgård: Jutland Archaeological Society, 2017).

Sovetskaya Arkheologiya

Die spätrömische Kaiserzeit und die frühe Völkerwanderungszeit in Mittel- und Osteuropa, ed. M. Mączyńska, T. Grabarczyk (Łódź: UŁ, 2000).

Sprawozdania Archeologiczne

Studien zur Sachsenforschung

Superiores Barbari. Księga pamiątkowa ku czci Profesora Kazimierza Godtowskiego, ed. R. Madyda-Legutko, T. Bochnak (Cracow: UJ, 2000).

Terra Barbarica. Studia ofiarowane Magdalenie Mączyńskiej $w$ 65. rocznicę urodzin, ed. A. Urbaniak et al. (Łódź / Warsaw: Instytut Archeologii UŁ, 2010).

The Treasures of Suchań, Pomeranian Archaeological Collections of the National Museum in Szczecin, vol. 1, ed. K. Kowalski, A. Bursche (Szczecin: Muzeum Narodowe w Szczecinie, 2014). The Turbulent Epoch. New Materials from the Late Roman Period and the Migration Period, ed. B. Niezabitowska-Wiśniewska et al. (Lublin: UMCs, 2008).

Ubi tribus faucibus fluenta Vistulae fluminis ebibuntur. Jerzy Okulicz-Kozaryn in memoriam, ed. B. Kontny (Warsaw: Instytut Archeologii UW, 2015).

Veg. Hist. Archaeobot. Vegetation History and Archaeobotany

Völker an Nord- und Ostsee und die Franken. Akten des 48. Sachsensymposiums in Mannheim vom 7. bis 11. September 1997, ed. U. von Freeden et al. (Bonn: Habelt, 1999).

Die Völker an der mittleren und unteren Donau im füften und sechsten Jahrhundert, ed. H. Wolfram, F. Daim (Vienna: Österreichische Akademie der Wissenschaften, 1980).

Vostochnaya Evropa $v$ seredine I tysyacheletiya n.e., ed. I. Gavritukhin, A. Oblomskiy (Moscow: Institut Archeologii Rossiyskoy Akademii Nauk, 2007).

Wiadomości Archeologiczne 
Wandel

Weapons

$W N$

Worlds Apart

Zaginione ocalone

Zwischen Byzanz und der Steppe

Zwischen Römern und Barbaren

\section{Zwischen Spätantike}

Wandel durch Migration? 26. internationales Symposium „Grundprobleme der frühgeschichtlichen Entwicklung im mittleren Donauraum“, Straubing, 2014, ed. H. Geisler (Büchenbach: Dr. Faustus, 2016).

Weapons, Weaponry and Man. In memoriam Vytautas Kazakevičius, ed. A. Bliujienè (Klaipėda: Klaipėda University Press, 2007).

Wiadomości Numizmatyczne

Worlds Apart? Contacts across the Baltic Sea in the Iron Age. Network Denmark-Poland, 2005-2008, ed. U. Lund Hansen, A. Bitner-Wróblewska (Copenhagen / Warsaw: Det Kongelige Nordiske Oldkriftselskab / Państwowe Muzeum Archeologiczne, 2010).

Zaginione - ocalone. Szczecińska kolekcja starożytności pomorskich / Lost-Saved. The Pomeranian Antiquities Collection of Szczecin, ed. K. Kowalski, D. Kozłowska-Skoczka (Szczecin: Muzeum Narodowe w Szczecinie, 2012).

Zwischen Byzanz und der Steppe. Archäologische und historische Studien: Festschrift für Csanád Bálint zum 70. Geburtstag / Between Byzantium and the Steppe: Archaeological and Historical Studies in Honour of Csanád Bálint on the Occasion of His 7oth Birthday, ed. A. Bollók, G. Csiky, T. Vida (Budapest: Institute of Archaeology, Research Centre for the Humanities, Hungarian Academy of Science, 2016).

Archäologie zwischen Römern und Barbaren. Zur Datierung und Verbreitung römischer Metallarbeiten des 2. und 3. Jahrhunderts n. Chr. im Reich und im Barbaricum - ausgewählte Beispiele (Gefäße, Fibeln, Bestanteile militärischer Ausrüstrung, Kleingerät, Münzen), ed. H.-U. Voß, N. Müller-Scheeßel (Bonn: Habelt, 2016).

Zwischen Spätantike und Frühmittelalter. Archäologie des 4. bis 7. Jahrhunderts im Westen, ed. S. Brather (Berlin / New York: De Gruyter, 2008). 


\title{
East Germanic and Alano-Sarmatian Finds of the Early Migration Period in the Roman West
}

\author{
Michel Kazanski
}

This chapter concentrates upon the discoveries of archaeological items that can be linked to the presence of East Germanic people, Alans and Sarmatians ${ }^{1}$ in the territory of the Western Empire in the initial stage of the Age of Migration (AD approx. $375^{-450)} .^{2}$ We must remember that the Barbarians on Roman territory were very few compared to the dense Roman population. They were scattered over a large area and did not always form compact enclaves of population. Thus archaeological findings related to Barbarians in one way or another are insignificant compared to the mass of Roman archaeological material. Moreover, the Barbarians held specific positions within the Empire's social structure - they were mostly warriors, slaves, or much more rarely agricultural settlers. They were thus often excluded from the process of production of material goods, on which archaeology is based - the Barbarians rarely had their own architecture, ceramics, tools, utensils, etc. Their cultural characteristics can appear only in made-to-order items, such as weaponry, jewellery, etc. ${ }^{3}$ Finally, in most cases, the Barbarians in the service of Rome essentially sought to integrate into Roman life, of course at a higher social level. Thus, the Barbarians willingly entered the Roman army and almost never betrayed their oath, trying to achieve a high military rank, such as Victor, a Sarmatian, who became a consul in 369, or the famous Alan leader Ardabur and his son Aspar.

The prestige of the Roman military fashion to the Barbarians must be noted - this developed into a common fashion for the costume and equipment

1 Note that at the beginning of the Age of Migrations, the designation "Alan" referred to all the steppe peoples of the Ponto-Caucasian region, while the Sarmatians occupied the steppes in the Carpathian Basin, east of the Danube.

2 This does not include the "princely" discoveries of the Untersiebenbrunn horizon (see Chapter 6), whose civilisation was a synthesis of various cultural components, including East Germanic and Alano-Sarmatian. On these, see Kazanski 1996a and Kazanski 2009, 238-245. On the other hand, cultural features of Alano-Sarmatian origin, such as artificial cranial deformation or metal mirrors with a hanging handle in the centre, also remain out with our study, because in the Age of Migrations these elements become international.

3 See detail: Kazanski, Périn 2008; Périn, Kazanski 2011; Kazanski, Périn 2017. 
of barbarian warriors. The representation of Stilicho, half-Vandal/half-Suevian, and Commander-in-Chief of the Army of the West, enables us to assess the level of Romanisation of Barbarians in the service of the Empire.

Female costume was more traditional and kept its "ethnographic" features longer. ${ }^{4}$ However, one must take account of the number of mixed marriages between Barbarians of various origins, as evidenced by the lives of Stilicho or Aspar. Unfortunately, the surviving evidence on these is essentially about the barbarian aristocracy, but the practice was undoubtedly widespread among "ordinary" Barbarians.

East Germanic combs and brooches have attracted researchers' attention for a long time; first, in relation to the problem of the archaeological traces of the Visigoths in the $5^{\text {th }} \mathrm{c}$. in the Roman West. ${ }^{5}$ Works published in the 198 os have now lost weight to a considerable extent, firstly because of the great expansion of known evidence, and secondly because the direct connection drawn between this material and the Visigothic migrations seems too simple. Archaeological evidence of the Alans and Sarmatians in the West has been the subject of several works. ${ }^{6}$ Today it is clear that East Germanic and Alano-Sarmatian finds in the West represent heterogeneous population groups of eastern European origin (Goths, Alans, Sarmatians, Taifali and others), who penetrated the Imperial territory in various ways: by military invasion, incorporation into the Roman army, as prisoners of war settled by the Romans, and more . ${ }^{7}$

Here we shall discuss the finds from northern and eastern Gaul, and the Rhine areas, which formed a part of the empire until the $460 \mathrm{~s}-470 \mathrm{~s} \mathrm{AD}$, from southern Gaul and Spain, at that time controlled by the Visigoths, and also from Italy and southern Germania, which in this period formed a part of the province of Raetia, and finally, from Britain. It is easy to see that a large proportion of artefacts under examination consists of elements of female costume. This is not a surprise as in "traditional" societies the women's costume of the main bulk of the population keeps its "ethnographic" features much longer than men's, which is oriented towards prestigious warriors' fashion. ${ }^{8}$

4 See in particular Kazanski, Périn, 2008, 196-198; Périn, Kazanski 2011, 315-321; Kazanski, Périn 2017, 202.

5 E.g. Koenig 1980; Kazanski 1984; 1985.

6 Kuznetsov 200o; Kazanski 2013b.

7 For details see: Kazanski 1993; Kazanski, Mastykova, Périn 2008; Kazanski 2010c; 2012; 2013b; López Quiroga 2015.

8 This is documented particularly by archaeological finds from the 4 th and early $5^{\text {th }}$ c. related to northern and western Germans in northern Gaul (Böhme 1974b). It is worth considering how Roman law prohibited marriages of barbarians and Roman citizens, therefore soldiers of 
Northern and eastern Gaul and Roman Germania is one of most thoroughly researched zones from the point of view of eastern European barbarian elements represented there by the finds of particular items in settlement layers and a small number of graves (Map 25.1). ${ }^{9}$ The most demonstrative East Germanic goods are probably single-sided horn combs of type Thomas III (Fig. 25.1.1-19). In eastern Europe their relationship with the Chernyakhiv ${ }^{10}$ context is unquestionable. The date of these combs is a little broader than the chronology of the early stage of the Migration Period, enveloping, it is generally accepted, also the Roman Period, and specifically Stage $\mathrm{C}_{3}$ of the European Barbaricum framework (the $\left.300 \mathrm{~s} / 3^{20 \mathrm{~S}-} 35 \mathrm{os} / 37 \mathrm{OS} \mathrm{AD}\right),{ }^{11}$ or at least its latest phase. The overwhelming majority of these combs in the West are chance finds, or originate from the layers of Later Roman towns and forts. ${ }^{12}$ These finds are mostly concentrated in the Rhine basin, on the eastern Gallic border (Map 25.1). However, recent finds have revealed Thomas type III combs also in the opposite corner of Gaul, in the Lower Loire basin, in vicinity of Angers, Maine-et-Loire district (France; Map 25.1:3). ${ }^{13}$

I know only one undoubtedly "western" find of a comb of type Thomas III in a funeral context from the period in question. This is grave 1 of the Later Roman cemetery of Oberwinterhur, Oberwinterhur district, Switzerland. ${ }^{14}$ This grave contained the remains of a skeleton of an adult, 30-35 years old, with the head to the south-west. Only the top of the skeleton and the lower fragment of right leg survived. The comb lay by the skull (Fig. 25.1:19), together with the worked tubular bone of a ruminant. The earliest stage of the Age of Migrations probably also has another find from the Upper Rhine area, from the cemetery of Herten, Nordrhein-Westfalen district. ${ }^{15}$ However, the grave from which this comb came is not known (Fig. 25.1:17); other published finds from the site could in fact be dated to the Merovingian Period.

There is a small series of finds of crossbow brooches with a returned foot of the type Ambroz 16/2, Series 1, Variants 2-3 (Fig. 25.1:30-34), typical of the

barbarian origin in the Roman service had to search for fiancées in Barbaricum. This could be a partial explanation for the appearance of rather numerous elements of barbarian woman's costume in archaeological sites located within the Empire. Kazanski 1993; 1998; 2012; Tejral 2016c.

$10 \quad$ See Chapter 22.

11 See Chapter 5.

12 Kazanski 1993, 175.

13 This comb found in Andard, Maine-et-Loire district, France, east of the town of Angers, was discovered by contract excavations of a Later Roman settlement, with 4th-c. coins and Roman red slip vessels. I am obliged to Jean Brodeur for the information on this find. Windler 1995, 181,182, fig. 5 . 


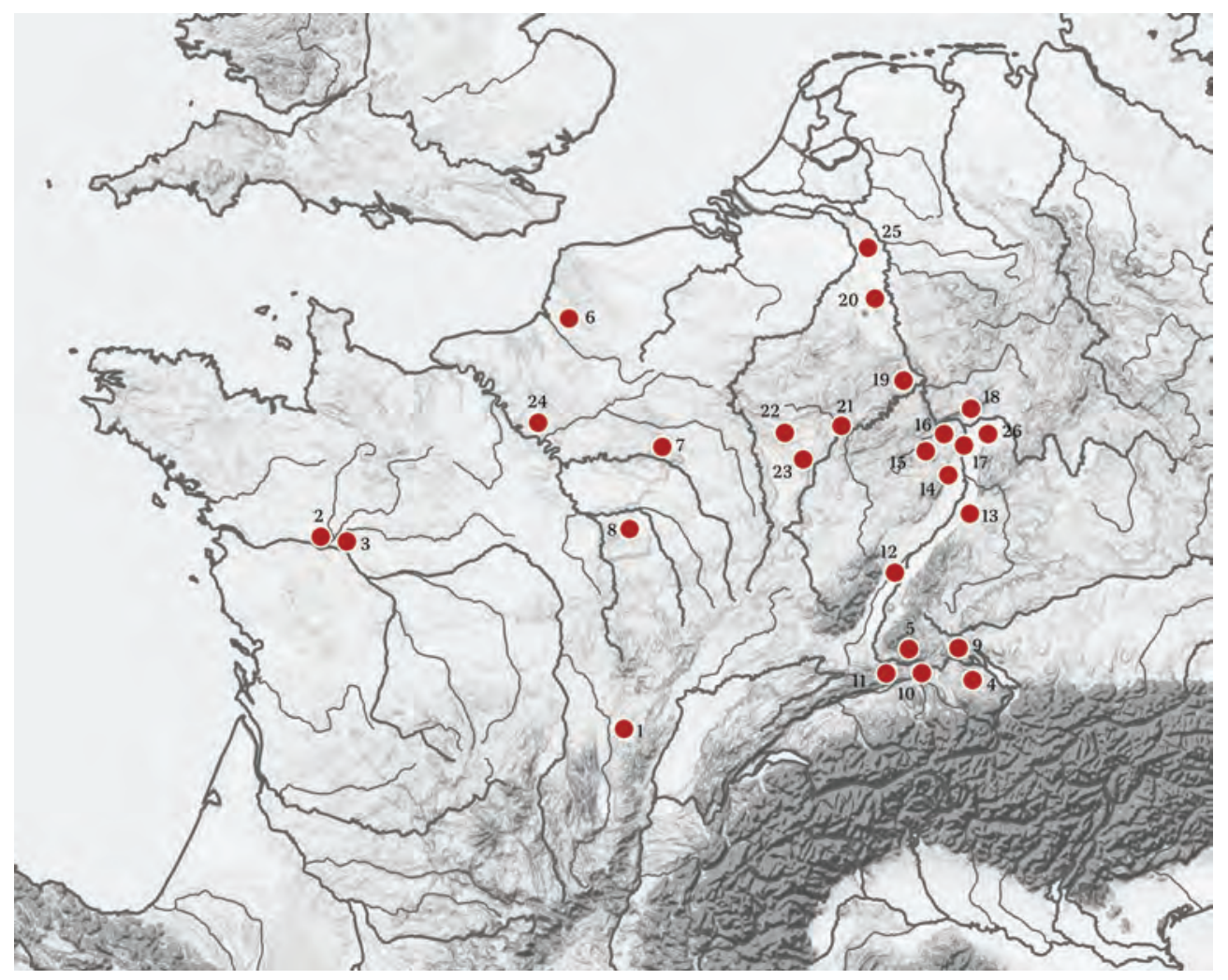

MAP 25.1 East Germanic and Alano-Sarmatian finds in northern and eastern Gaul: 1 - Baudemont, Saône-et-Loire district; 2 - Angers, Maine-et-Loire district; 3 - Andord, Maine-et-Loire district; 4 - Oberwinterhur, Oberwnterhur district; 5 - Herten, Nordrhein-Westfalen district; 6 - Nouvion-en-Ponthieu, Somme district; 7 - Reims, Marne district; 8 - Troyes, Aube district; 9 - Ebersberg, Zürich district; 10 - Kaiseraugst, Rheinfelden district; 11 - Basel, Basel-Stadt; 12 - Strasbourg, Bas-Rhin district; 13 - Mungolsheim, Baden-Württemberg; 14 - Ruppertsberg, Rheinland-Pfalz district; 15 - Eisenberg, RheinlandPfalz; 16 - Bad Kreuznach, Rheinland-Pfalz; 17 - Alzey, Rheinland-Pfalz; 18 - Wiesbaden, Hessen district; 19 - Polch-Ruitsch, Rheinland-Pfalz; 20 Köln, Nordrhein-Westfalen district; 21 - Trier, Rheinland-Pfalz; 22 - Rihmberg, Luxemburg; 23 - Dalheim, Remich district; 24 - Flins-sur-Seine, Yvelines district; 25 - Krefeld-Gellep, Nordrhein-Westfalen district; 26 - Trebur, Hessen district 

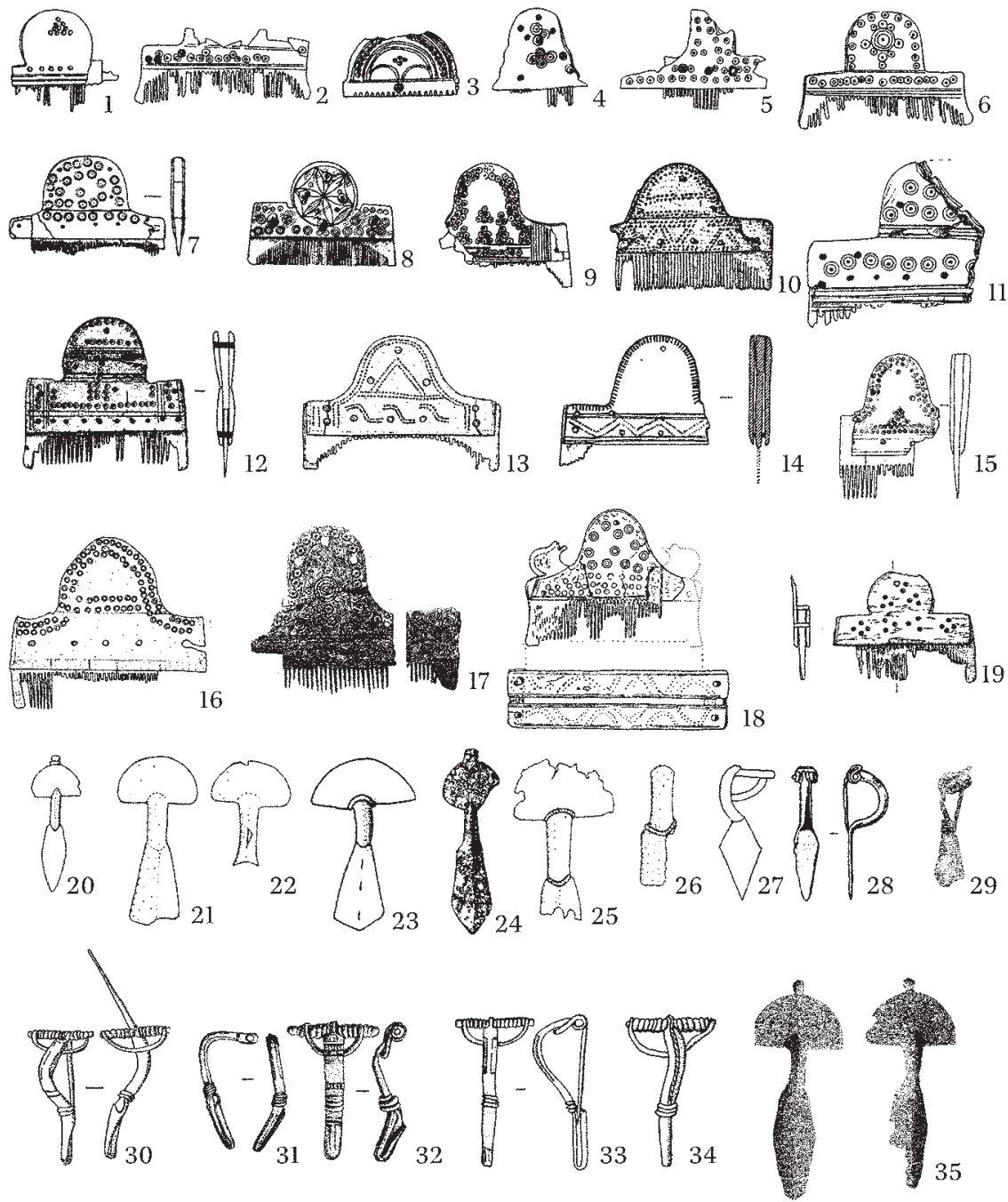

FIGURE 25.1 East Germanic artefacts in northern and eastern Gaul:

1-6 - Trier, Rheinland-Pfalz; 7 - Polch-Ruitsch, Rheinland-Pfalz; 8 - Köln,

Nordrhein-Westfalen district; 9, 10 - Wiesbaden, Hessen district; 11 -

Kaiseraugst, Rheinfelden district; 12, 13 -Alzey, Rheinland-Pfalz; 14 - Eisenberg, Rheinland-Pfalz; 15, 16 - Bad Kreuznach, Rheinland-Pfalz; 17 - Herten,

Nordrhein-Westfalen district; 18 - Mungolsheim, Baden-Württemberg; 19 Oberwinterhur, Oberwnterhur district; 20 - Strasbourg, Bas-Rhin district; 21, 22 - Saône Valley; 23 - Marne district; 24 - Basel, Basel-Stadt; 25, 26 - possibly Eastern France; 27 - Wiesbaden; 28 - Ebersberg, Zürich district; 29, 35 Baudemont, Saône-et-Loire district; 30 - Rihmberg, Luxemburg; 31 - Dalheim, Remich district; 32, 33 - Trier, Rheinland-Pfalz district; 34 - Ruppertsberg, Rheinland-Pfalz district (1-16, 18, 20-28, 30-34 after: Kazanski 1993; 17 after: Garscha 1970; 19 after: Windler 1995; 29, 35 after: Kasprzyk 2011) 
Chernyakhiv Culture from the $3^{\text {rd to }} 5^{\text {th }}$ c. although also occurring in Central European finds, particularly of the Wielbark Culture. ${ }^{16}$ They also concentrate in the Rhine border of the Empire, and in the Mosel basin. All these brooches originate from the layers of towns, forts, and settlements. ${ }^{17}$

Crossbow brooches with a cast diamond foot, of the type Ambroz 17/3, variant $\mathrm{v},{ }^{18}$ also belonged to the Chernyakhiv Culture tradition and were typical of the final stage of that culture. There are two finds of these on the Rhine (Fig. 25.1:27-28). ${ }^{19}$

The finds in Gaul include two brooches with a returned foot that is widened and sting-shaped, of the type Ambroz $16 / 4$, Series $3 \cdot{ }^{20}$ In the context of eastern and central Europe these brooches have a relatively wide chronology, which envelopes the whole Later Roman Period. Outside the Chernyakhiv Culture area, brooches with a diamond foot-plate similar to the pieces from Gaul are reliably documented in closed assemblages from the Migration Period and even in the Post-Chernyakhiv Period, such as in grave 300 of the Gothic cemetery of Diurso, Krasnodar district (Russia), in vicinity of modern Novorossiisk, or in grave 79 of the Hispano-Visigothic cemetery of Duratón, Segovia district (Spain), which will be discussed below. ${ }^{21}$ One brooch (of silver, $4 \mathrm{~cm}$ long) comes from eastern Gaul (Fig. 25.1:29), where it was found in 1894 during excavations of the cemetery of Baudemont, Saône-et-Loire district (France). This site dates from the 4 th and $5^{\text {th }}$ c., and the exact context of the find is not known. In total this cemetery produced about 30 inhumations, with the heads oriented to the west except for one inhumation grave with the head to the north. ${ }^{22}$ This cemetery also contained a pair of large radiate-headed brooches of type Smolin, and, as we will see later, two radiate-headed brooches derivative of type Ambroz 1BA. The publisher correctly concluded that these all testify to the presence of an East Germanic element.

The second brooch of this type originates from grave 54 of the cemetery of Nouvion-en-Ponthieu in Picardy, Somme district (France), which dates back to the Later Roman but mostly to the Merovingian Period (Fig. 25.2:2). This grave was destroyed by the removal of soil. It contained an inhumation, with the head to the north; the skeleton was prone, and disturbed grave goods were in the fill of the grave pit. They comprised a silver brooch with a returned foot, of

Ambroz 1966, 6o-66; Kokowski 1995, fig. 6o, 61.

17 Kazanski 1993, 175, 176; 1998, 375, 376.

18 Ambroz 1966, 72.

19 See Kazanski 1993, 176; Kazanski 1998, 376.

20 Ambroz 1966, 69. 

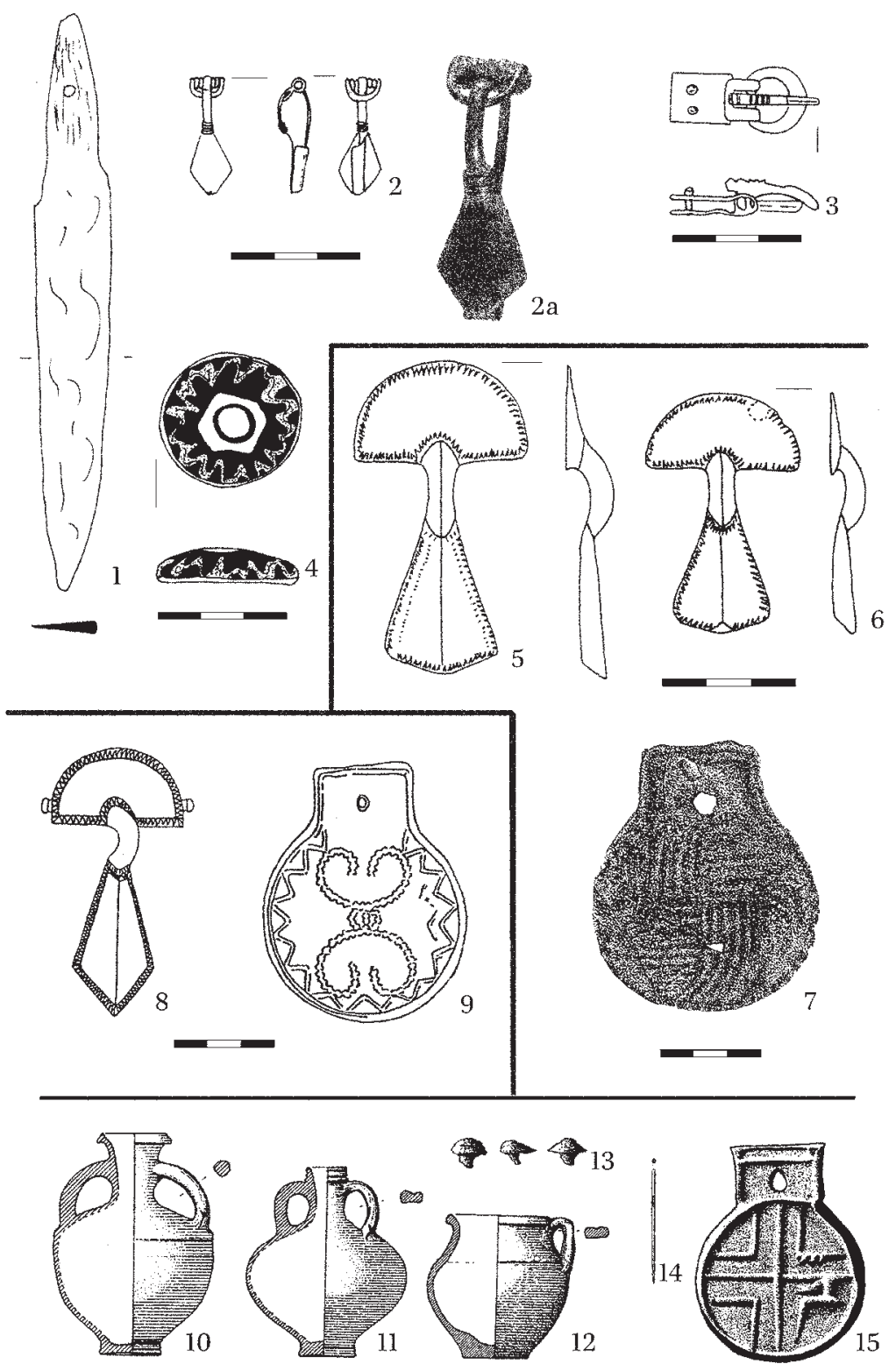

FIGURE 25.2 Artefacts from graves in northern and eastern Gaul:

1-4 - Nouvion-en-Pinthieu, Somme district, grave 54; 5, 6 - Troyes, Aube district, the cemetery of Saint-Jacques, grave 2; 7 - Troyes, Aube district, the cemetery of Saint-Jacques, grave 4; 8, 9 - Reims, Marne district, the cemetery of Fosse-Jean-Fat; 10-15; Krefeld-Gellep, Nordrhein-Westfalen district, grave 4607 (1-4 after: Piton 1985; 5-7 after: Riffaud-Longuespé 2003; 8, 9 after: Kazanski 1986; 10-15 after: Kazanski 1993) 
the type in question, measuring $2.8 \mathrm{~cm}$ in length, a small buckle with a rectangular frame and a long tongue turned down, a knife, and a bead of transparent green glass, with yellow applied decoration. The buckle (Fig. 25.2:3) is typical of the early stage of the Migration Period and most probably dates from about the mid- 5 th c. ${ }^{23}$

Small (less than $8 \mathrm{~cm}$, without the knob) radiate-headed brooches of types Ambroz IAA, ІАБ, rarely IБA ${ }^{24}$ and their larger derivatives $(8$ to $10 \mathrm{~cm}$, without the knob) form the most outstanding series of the Chernyakhiv brooches in northern and southern Gaul, from the Rhine to the Lower Loire (Fig. 25.1:20-26; Fig. 25.2:5-6, 8, Fig. 25.2:8; Fig. 25.3B). Some of these have come from graves. ${ }^{25}$

It would be difficult to establish whether two brooches from Cholet, Main-et-Loire district (France) in western Gaul and a similar brooch from Nijmegen, Gelderland district (Netherlands) in the Lower Rhine area (Fig. 25.3A:3-4) belong to the Chernyakhiv group. On the one hand, they definitely resemble the Chernyakhiv pieces, ${ }^{26}$ but on the other hand are also similar to brooches of type Burk, Bautzen district (Germany) and Kuhbier, Brandenburg district (Germany; Fig. 25.3A:1-2), that were distributed among the Germanic folk of the Elbe - Oder area. ${ }^{27}$

A pair of silver radiate-headed brooches of type Ambroz IAA (8.8 cm long), in combination with a Sarmatian mirror with a side loop, was discovered in a child's grave in the Gallo-Roman cemetery of Fosse-Jean-Fat, in the city of Reims, Marne district (France), in Champagne (Fig. 25.2:8-9). From Notitia Dignitatum it is known that in the Western Roman Empire the security of the strategic road between Reims and Amiens was provided by Sarmatian gendarmes commanded by the Praefectus Sarmatarum gentilium. ${ }^{28}$

Another grave containing such brooches was discovered in Troyes, Aube district (France) in Champagne, in the Gallo-Roman cemetery of Saint-Jacques. In 1928, 26 graves from the Gallo-Roman Period were uncovered there. Grave 2 contained three silver radiate-headed brooches, two pieces of smaller size, measuring $5 \mathrm{~cm}$, and one larger, of $7 \mathrm{~cm}$, all of the type Ambroz IAB (Fig. 25.2:5$6)$; and a red-slip plate of type Chenet 320 characteristic of the 4th and early $5^{\text {th c. }}{ }^{29}$ Emblematically, grave 4 in the same cemetery contained a Sarmatian mirror with a side loop (Fig. 25.2:7). These, as at Reims, are circular metallic

\footnotetext{
23 Piton 1985, 39, pl. 10.54.

24 Ambroz 1966, 76-86.

$25 \quad$ Kazanski 1993, 175; 1998, 376.

26 Koenig 1980, 229, 230, fig. 2, tab. 6o.a - b.

27 Kazanski 1992, 116, fig 7.1, 7.2.

28 Kazanski 1986.

29 Riffaud-Longuespé 2003, 34, pl. 1.d - e.
} 

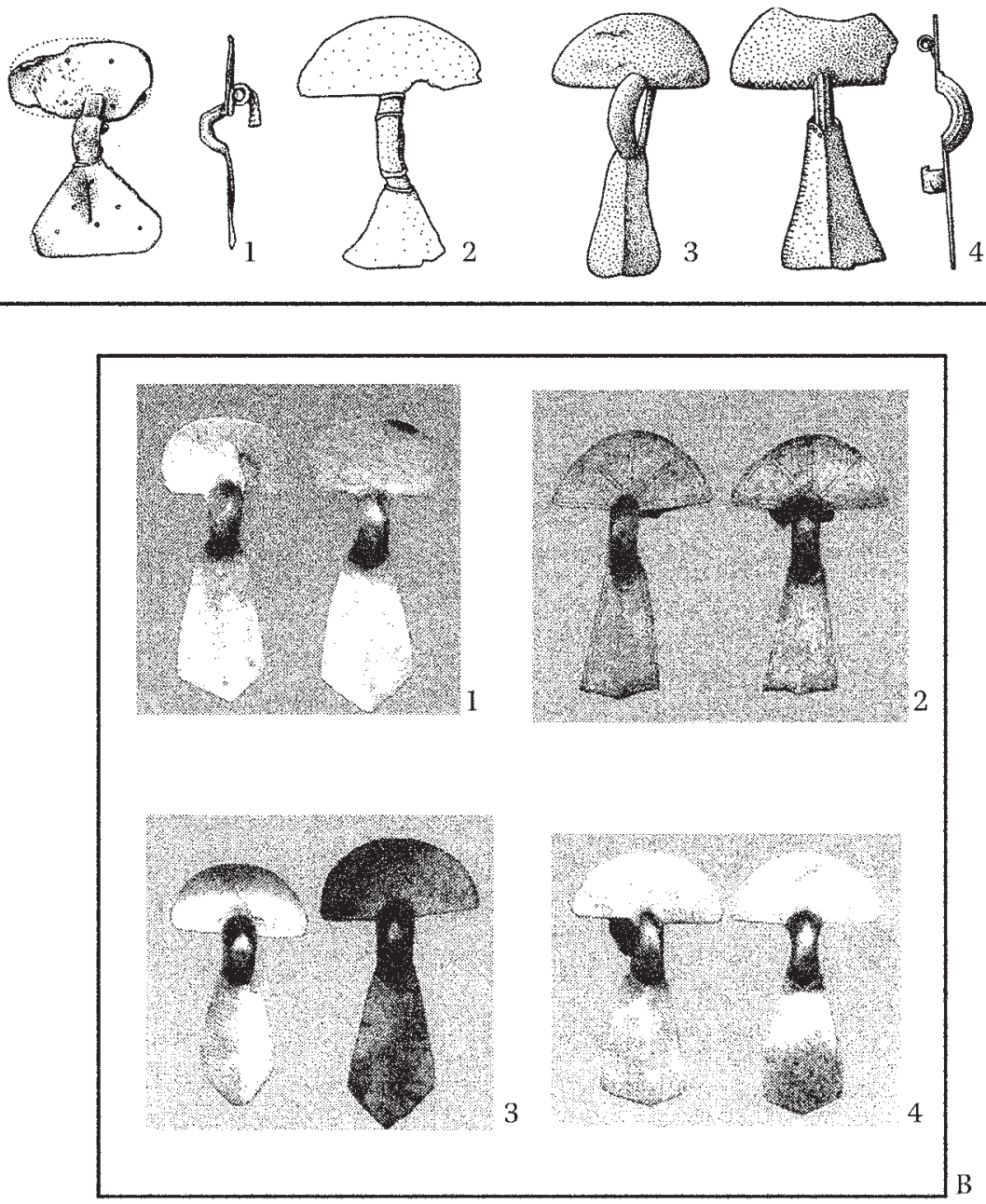

FIGURE 25.3 Radiate-headed brooches from northern Gaul. A - Brooches from Cholet and Nijmegen and their probable prototypes: 1 - Burk, Bautzen district; 2 - Kuhbier, Brandenburg district; 3 - Nijmegen, Gelderland district; 4- Cholet, Main-et-Loire district (after: Koenig 1982 and Kazanski 1990-1991). B - Radiate-headed brooches from Angers, Maine-et-Loire district: 1 - grave 134; 2 - grave 155; 3 - grave 156; 4 - grave 159 (after: Brodeur, Morteau, Yvinec 2001) 
mirrors having a perforated rectangular protrusion for hanging. In grave 4607 of the Rhineland cemetery of Krefeld-Gellep, Nordrhein-Westfalen district (Germany), ${ }^{30}$ such a mirror was accompanied by typically Roman ceramics of the second half of the 4th c. (Fig. 25.2:10-15).

Another two silver radiate-headed brooches of relatively large size, derivatives of type Ambroz 1BA (Fig. 25.1:35), appeared in the already-noted cemetery of Baudemont, in eastern Gaul. ${ }^{31}$

The most interesting finds are from the Gallo-Roman cemetery of Gare Saint-Laud in Angers, in the Loire basin, a site which is still awaiting publication. This is an urban cemetery of a local population, comprising typical inhumations of the Later Roman tradition, with the heads oriented to the west, except for a few graves with the heads to the north. Four graves, female according to osteological analysis, contained pairs of small silver radiate-headed brooches of type Ambroz IAA (Fig. 25.3B), although the skeletons with a northerly alignment, anthropologically determined as male, were accompanied by oval iron belt buckles. These graves are distinguished by the unusual orientation of skeletons, the grave goods, and secondary anthropological features. The foreign, most likely eastern European origin of this population is obvious. ${ }^{32}$

It is therefore possible to observe that in northern and eastern Gaul, East Germanic artefacts related primarily to the Chernyakhiv Culture are concentrated in the vicinity of the Rhine limes. There are zones of concentration of these artefacts in the vicinity of Argentoratum (Strasburg) and Mogontiacum (Mainz), where, according to Notitia Dignitatum, specific commands were established by AD 400, thus underlining the strategic importance of these towns. On the northern sector of the border, that is to say in the Lower Rhine area, where defence was secured by the foederati of the Franks, there is practically no East Germanic artefact. ${ }^{33}$ Chernyakhiv finds also occur in inner regions of northern and western Gaul: there they could be related, in some cases, to military settlers, who formed something like a field gendarmerie. It is significant that the Alano-Sarmatian objects are spread more widely in northern Gaul and are not focused on the border. ${ }^{34}$ It is also significant that the graves with East Germanic and Alano-Sarmatian items contain rather heterogeneous

\footnotetext{
30 Kazanski 2013b, fig. 3.10-14.

$31 \quad$ Kasprzyk 2011, 341, 342, fig. 3.1-4.

32 Brodeur, Morteau, Yvinec 2001; Briceno, Souquet-Leroy, Guillon 2013.

33 Kazanski 1993, 178.

34 It may be no coincidence that Notitia Dignitatum also mentions a Praefectus Sarmatorum and Taifalorum gentilium for the region of Poitiers (Notitia Dignitatum, Oc. XLII, 65). This officer could have commanded both Sarmatians and Taifals, i.e. Germanic men from the Lower Danube.
} 
grave goods, of both Roman (ceramics, bracelets, beads) and Germanic origins (brooches), showing the mixed culture of this population. Apart from a few "barbaric" items, these graves are indistinguishable from those of the Roman population. We can thus infer that the integration of holders of such exotic objects was very deep.

Recently, a few of the Alano-Sarmatian arms were discovered in Gaul (Fig. 25.4), but their cultural context is not always clear. ${ }^{35}$ It is quite possible that these weapons have arrived in the West through the Middle Danube, where they are attested in the Hunnic era or with the Visigoths of the Lower Danube, where these blades are known for the 4 th c. ${ }^{36}$

According to reliable written sources, in the $5^{\text {th }}$ c. southern Gaul and Spain were a zone populated by the Visigoths (Map 25.2). There are a few artefacts of Chernyakhiv appearance, initially identified in Aquitania ${ }^{37}$ and then in Spain. ${ }^{38}$

Similarly to northern Gaul, there were combs of type Thomas III (Fig. 25.5:3$6,16)$ : some were discovered in the excavations of Later Roman villas and, rarely, of forts, e.g. Bergidum, modern Cacabelos, Castro Ventosa, Léon district, in the north-west of Spain. ${ }^{39}$

The second outstanding category of East Germanic artefacts comprises crossbow brooches with a returned foot of type Ambroz 16/2, Series 1, Variants 2 and 4 (Fig. 25.5:1-2,12-13). These brooches have been found both in Aquitania and Spain, particularly in layers of Late Roman villas, which will be described below. ${ }^{40}$

There also is a brooch of the above-mentioned type Ambroz 16/4.III, ${ }^{41}$ from grave 79 of Spanish-Visigothic cemetery of Duratón, Segovia district (Spain), in Old Castile (Fig. 25.5:9). This is an inhumation grave of an adult, oriented to the west. It contained a typical female costume of the East Germanic tradition, which was well represented in Visigothic Spain, comprising two large radiate-headed brooches on the chest and a large buckle with a rectangular frame. ${ }^{42}$ This costume of Danubian origin most probably appeared amidst the Visigoths from the migration of certain Ostrogothic groups, such as the

35 Lebedynsky 2012, fig. 19.

36 Magomedov, Levada 1996, fig. 3; Soupault 1996; Levada 2013 b.

37 Kazanski 1985; Kazanski, Lapart 1995; Pinar Gil 2015.

38 Pérez Rodriguez-Aragón 1996; 1997; 2008, 252; López Quiroga 2010, 126; 2015, 481, 482.

39 See Kazanski 1985; Kazanski, Lapart 1995; Cases, Passelac 2014; Pérez Rodriguez-Aragón 1996, 173, fig. 1; 1997, 629, fig. 1.1; 2008, fig. 4.31; López Quiroga 2010, 126, fig. 92; 2015, fig. 6.

40 Kazanski, Lapart 1995, 198; Pérez Rodriguez-Aragón 1996, 176, 177, fig. 3.1, 3.2; 1997, 629, fig. 1.5 1.6; 2008, fig. 4.28, 4.29; Kazanski 1998, 375-376; 1999b, 15; 2000, 192, 193.

41 Pérez Rodriguez-Aragón 1996, 177, fig. 3.4; 1997, 629, fig. 1.2; 2008, fig. 4.30; Kazanski 2000, 193, 194 . 

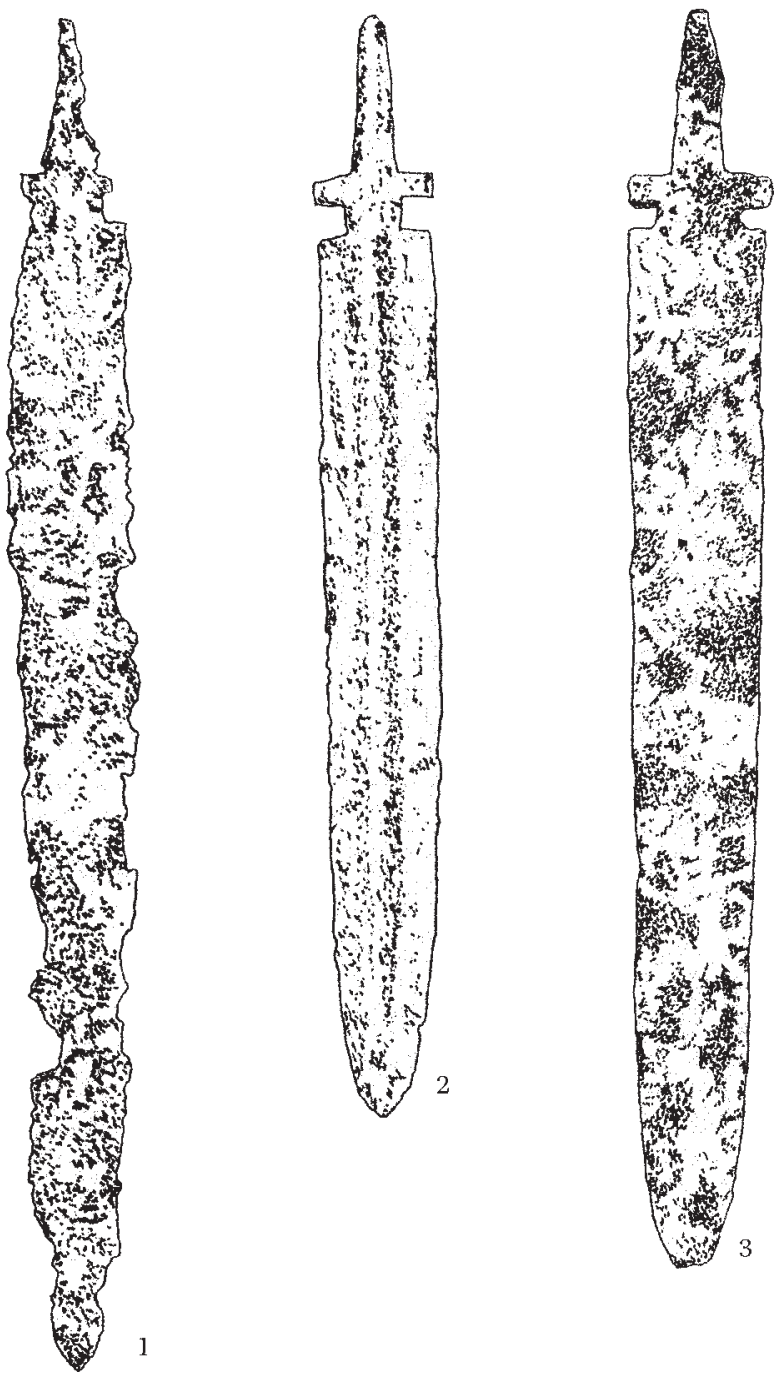

FIGURE 25.4 Blades with two notches near the handle, discovered in Gaul: 1, 2 - Villeneuve-sur-Lot, Lot-et-Garonne district; 3 - Flins-sur-Seine, Yvelines district (after: Lebedynsky 2012) 


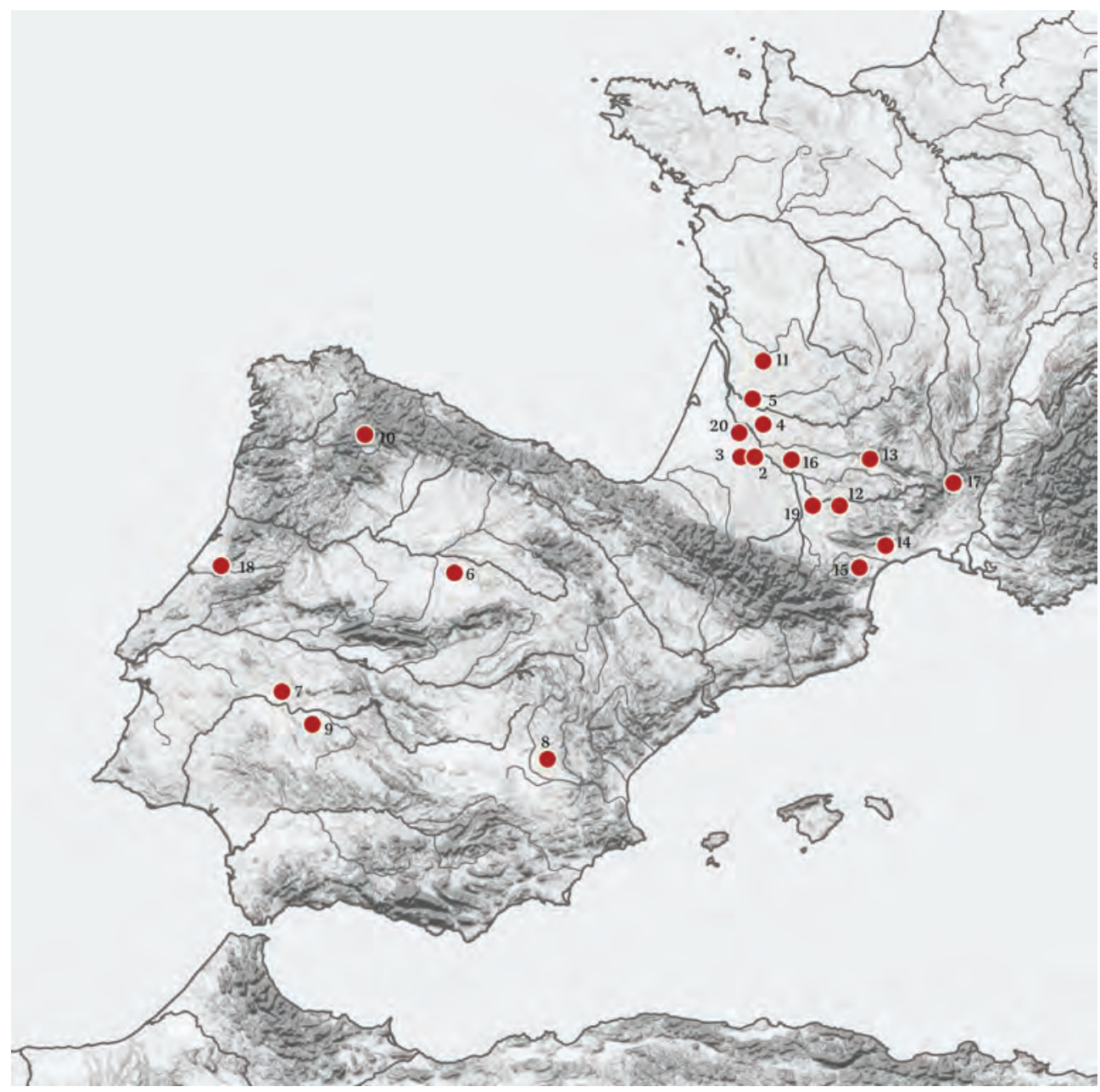

MAP 25.2

East Germanic and Alano-Sarmatian finds from southern Gaul and Spain: 1- Beaucaire-sur-Baïse, Gers district; 2 - Séviac-Montréal-du-Gers, Gers district; 3- Bapteste, Lot-et-Garonne district; 4-Sainte-Baselle, Lot-et-Garonne district; 5 - Canet, Dordogne district; 6 - Duratón, Segovia district; 7 - El Hinojal, Badajos district; 8 - Casa de la Zua, Albacente district; 9 - Badajoz, Badajos district; 10 - Cacabelos, Castro Ventosa, Léon district; 11 - Jonzac, Charente-Maritime district; 12- Quarante, Hérault district; 13 - Rodelle, Aveyron district; 14 - Aspiran, Hérault district; 15 - Roujan, Hérault district; 16 - Vindrac, Tarn district; 17 - Montmirat, Gard district; 18 - Coimbriga, Coimbra district;19 - Mireval-Laurgais, Aude district; 20 - Villeneuve-sur-Lot, Lot-en-Garonne district 

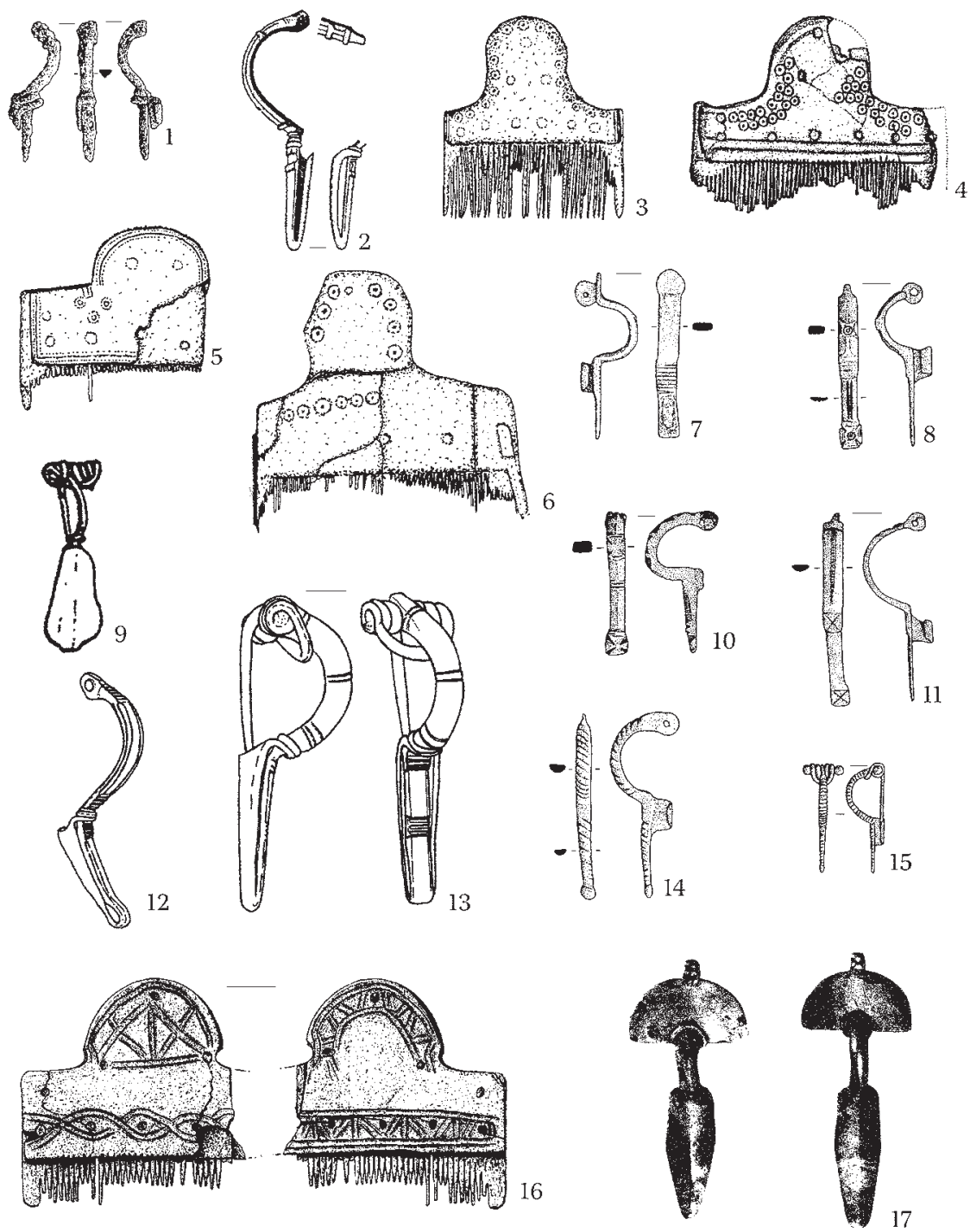

FIGURE 25.5 East Germanic artefacts from southern Gaul and Spain: 1 - SainteBaselle, Lot-et-Garonne district; 2 - Canet, Dordogne district; 3 - Séviac-Montréal-du-Gers, Gers district; 4 - Beaucaire-sur-Baïse, Gers district; 5, 6 - Bapteste, Lot-et-Garonne district; 7 - Quarante, Hérault district; 8 - Rodelle, Aveyron district; 9 - Duratón, Segovia district; 10 - Aspiran, Hérault district; 11 - Roujan, Hérault district; 12 - El Hinojal, Badajos district; 13 - Casa de la Zua, Albacente district; 14 - Vindrac, Tarn district; 15 - Montmirat, Gard district; 16 - Cacabelos, Castro Ventosa, Léon district; 17 - Badajoz, Badajos district (1, 2, 4 after: Kazanski 1999b; 3, 5, 6 after: Kazanski, Lapart 1995; 7, 8, 10, 11, 14, 15 after: Kazanski 1994b; 9 after: Molinero Perez 1948; 12, 12, 16 after: Pérez Rodriquez-Aragón 1997: 17 after: Koenig 1980) 
retinue and troop of Prince Vidimer Amal, who moved to the Visigothic court in the 470 . $^{43}$

A brooch with a returned foot of the Chernyakhiv tradition lay below the chin, near the cervical vertebrae. ${ }^{44}$ It was certainly in secondary use or was very old, since the other grave goods, and particularly the radiate-headed brooches and the large buckle, are typical of Hispano-Visigothic antiquities in the second half of the $5^{\text {th }} \mathrm{c}$. However, as we can see from the examples of the graves in Diurso and Nouvion-en-Ponthieu, this is not the only case of brooches of type Ambroz 16/4.II I being found in the Post-Chernyakhiv period.

It is also worth mentioning two small $(7.0$ and $7.3 \mathrm{~cm}$ long, excluding the knob) silver radiate-headed brooches of the Chernyakhiv tradition of type Ambroz IBA (Fig. 25.5:17), found at an unknown place in south-western Spain, perhaps from the vicinity of Badajoz, Badajoz district (Spain). ${ }^{45}$

From southern Gaul there are crossbow brooches with a platform on the back. A variant with a platform at the spring occurs as surface finds in Quarante, Hérault district (France; Fig. 25.5:7). This is a bronze crossbow brooch with a straight foot-plate, a short catch-plate, and a spring-holder shaped like a vertical perforated plate in continuance of the back-plate, and a semicircular shield at the spring-holder. The platform on the back-plate is recognizable de visu. ${ }^{46}$ The second variant comprises bronze shield-less brooches from Rodelle, Aveyron district (France), and Aspiran, Hérault district (France; Fig. 25.5:8, 10-11). ${ }^{47}$ The first piece originates from an inhumation grave (from the 1870 excavations), placed within a prehistoric dolmen. The brooch lay by the skull. No information is available concerning other grave goods. The second brooch was a surface find from a Gallo-Roman settlement, accompanied by a few fragments of grey polished, or "Early Christian", pottery ("DSP" in French archaeologists' jargon) from the Late Roman Period. These brooches have a pronounced platform on the end of the foot-plate, decorated with a crossed design, and a platform on the back-plate, also with crossed design. They are obviously related to two very similar brooches without back platforms (Fig. 25.5:10), one of unclear provenance and the other from Roujan, Hérault district (France), from a Gallo-Roman settlement, without any associated Late Roman finds . ${ }^{48}$ Similar brooches with crossed designs on the end of the foot-plate and no platform on the back-plate are known in Spain, particularly from the cemetery of Duratón,

\section{Périn 1993.}

44 Molinero Perez 1948, 34, Lám. 14.3.

45 Koenig 1980, 231, tab. 6o. c, d; Pérez Rodriguez-Aragón 1997, 631, fig. 6.3.

46 Feugère 1988, 10, fig. 5,5; Kazanski 1994b, 161-162; 1999b, 17; Pinar Gil 2015, fig. 2.2.

47 See Feugère 1988, 5, 6, fig. 2.2,4; Kazanski 1994b, 168; 1999b, 17.

48 Feugère 1988, 5, 6, fig. 2.3, 5 . 
and in Portugal, at Conímbriga, Coimbra district. ${ }^{49}$ It is thought that southern Gallic brooches with cross designs were preceded by crossbow brooches with a returned foot with an engraved design, well-known in the Chernyakhiv and the Wielbark Cultures. ${ }^{50}$ However the platform on the back of southern Gallic brooches resembles some brooches of the Wielbark and Dollkeim-Kovrovo Cultures. ${ }^{51}$ These brooches, typical of the Vistula basin, are combined under type Gródek 47.52 Although this type includes several variants, the feature of the platform at the spring-holder was not a criterion for classification. They date from the Later Roman Period, specifically Stages $\mathrm{C}_{2}-\mathrm{D} 2$, i.e. from the $260 \mathrm{~s} / 270 \mathrm{~s}$ to the $45 \mathrm{os} \mathrm{AD}$. Brooches of type Gródek 47 survived into the first half of the $5^{\text {th }} \mathrm{c}$. according to the find in the hoard of Frombork/ Frauenberg, near the Vistula estuary, with a coin from AD 433.

In the Migration Period, cross-bow brooches with specific relief decoration on the back and the bow appeared in southern Gaul (Fig. 25.5:14-15). They preceded the brooches of types Duratón and Estagel. ${ }^{53}$ They are known in Vindrac, Tarn district (France) and Montmirat, Gard district (France). ${ }^{54}$ These brooches are made of bronze. One piece is from a sarcophagus with a child's inhumation, where it made a pair with another similar brooch, without corrugation, which probably preceded type Estagel. One of these brooches lay at the waist, another, with remains of textile, on the left shoulder of the skeleton. In the Later Roman West, this way of wearing brooches is known only in traditional East Germanic costume. ${ }^{55}$ On the belt there also was an oval iron buckle. ${ }^{56}$ The second brooch, also of bronze, was discovered on the modern surface of a site of unknown character. Parallels to both brooches are known in Normandy and Spain, but they very probably date to the Early Merovingian Period. The chronology of southern Gallic brooches remains unclear. The prototypes for crossbow brooches with a corrugated body are Later Roman brooches, from Stages $\mathrm{C}_{2}-\mathrm{C}_{3}(\mathrm{AD} 260 / 270-360 / 370$ ), of smaller size but with the same decoration (Raupenfibeln), a relatively small catch-plate and a short foot-plate. ${ }^{57}$ They form the group labelled Schultze $21,{ }^{58}$ which more

\footnotetext{
49 Kazanski 1994b, fig. 6.8-6.11, López Quiroga 2015, fig. 14.45, 14.46.

50 Schulze-Dörrlamm 1986, 683.

51 Kazanski 1994b, 161-162; 1999b, 17; Pinar Gil 2015, 518, fig. 6.

52 Andrzejowski, Prochowicz, Rakowski 2008.

53 On which, see Schulze-Dörrlamm 1986, 643-650.

54 Kazanski 1994b, 165.

55 For details see Kazanski, Périn 2008, 196-198; Périn, Kazanski, 2011, 317-321; Pinar Gil 2015, 531-538.

56 Feugère 1988, 7 .

57 Kazanski 1994b, 168; Pinar Gil 2015, 522, 523, fig. 8.

$5^{8}$ Schultze 1977, 24, 25 .
} 
or less corresponds to M. Tuszyńska's series I of small corrugated brooches. ${ }^{59}$ These brooches are rather widespread in the southern Baltic Sea area. They are found in the former East Prussian territory, in the Lower Vistula area, and on the Baltic islands. It seems that the corrugated brooches appeared in the West as a result of certain contacts with southern Baltic zone and the Lower Vistula basin in the Migration Period.

As has already been mentioned, some of the artefacts from southern Gaul and Spain originate from the layers of the Later Roman villas. They comprise bronze brooches with a returned foot of type Ambroz 16/2, Series 1, Variants 2 and 4, in Canet, Dordogne district (France), in Aquitania, ${ }^{60}$ in El Hinojal/ las Tiendas, Badajos district in south-western Spain, in a layer with coins of Theodosius, ${ }^{61}$ and in Casa de la Zua, Albacente district in south-eastern Spain. ${ }^{62}$ In addition, combs of the Thomas II type have been found during excavations of villas in Aquitania, such as Beaucaire-sur-Baïse, Gers district (France), ${ }^{63}$ Séviac-Montréal-du-Gers, Gers district (France), ${ }^{64}$ Bapteste, Lot-et-Garonne district (France) ${ }^{65}$ and Mireval-Laurgais, Aude district (France). ${ }^{66}$

This relationship between East Germanic artefacts and villas in Aquitania may reflect the settlement of the Visigoths according to the so-called "hospitality law," granting the barbarians, as a reward for their military service, with one-third of the Roman population's real estate. ${ }^{67}$ However, W. Goffart has supposed that this law foresaw not the real expropriation of the property of Roman citizens, but a payment to the barbarians of one-third of money equivalent of its price. ${ }^{68} \mathrm{~W}$. Goffart's hypothesis raised a point of discussion. It seems that different forms of payment could occur in different regions of the Empire. In the case of southern Gaul and Spain, where the Visigoths found themselves as masters, they certainly practised direct occupation of Roman land. However, this view may be oversimplified. The finds of East Germanic artefacts in villas in Spain actually originate from the southern half of the Iberian Peninsula, although, according to the written sources, the Visigoths gained a foothold primarily in the northern half. Therefore, it is better for now to leave

Tuszyńska 1988, 179, 18 o.

Kazanski, Lapart 1995, 198, fig. 10.1; Kazanski 1998, 375, fig. 1.18.

Pérez Pérez Rodriguez-Aragón 1996, 176, 177, fig. 3.1; 1997, 629, fig. 1.2; Kazanski 2000, 192,194, fig. 1.8; 4.

Pérez Rodriguez-Aragón 1996, 176, 177, fig. 3.2; 1997, 629, fig. 1.3.

Kazanski 1985; Kazanski, Lapart 1995, 197, fig. 7-9; Kazanski 1999b, 15, fig. 1.2.

Kazanski, Lapart 1995, 197, fig. 3.3, 3.6; Kazanski 1999b, 15, fig. 1.2.

Kazanski, Lapart 1995, 197, fig. 3, 3.1, 3.2; Kazanski 1999b, 15 .

Cases, Passelac 2014.

Rouche 1979, 23, 161-169.

Goffart 1980. 
final conclusions as to why Chernyakhiv goods appear in the Late Roman villas contexts open.

In Italy, the presence of the Goths was episodic before the late $5^{\text {th }}$ c., i.e. before the establishment of Teodorich's Ostrogothic kingdom. Finds are very rare, actually restricted to the cemetery of Sacca di Goito, Mantova district (Italy), in the basin of the left bank of the Po, north of the city of Mantua. There is only a preliminary publication discussing the cemetery, ${ }^{69}$ which comprised inhumations from the age of the Late Empire. At least three graves contained brooches of the Chernyakhiv tradition with Sarmatian mirrors.

Grave 206 contained a pair of silver radiate-headed brooches of type Ambroz 1AA, measuring $6.3 \mathrm{~cm}$ in length, and two hemispherical gold foil appliqués (Fig. 25.6:3). ${ }^{70}$ In grave 210 there were a bronze radiate-headed brooch of the type Ambroz 1AA, measuring $4.5 \mathrm{~cm}$ in length, one bronze crossbow brooch with a cast foot-plate, measuring $3.9 \mathrm{~cm}$ in length, whose origin can be linked to eastern or central European Barbaricum in the Later Roman Period, ${ }^{71}$ a bronze bracelet, and a Sarmatian mirror with a side loop (Fig. 25.6:2). ${ }^{72}$ Finally, grave 214 contained a pair of radiate-headed silver brooches of type Ambroz 1AA, measuring $4.5 \mathrm{~cm}$ in length, a silver brooch with a returned foot of the frequently mentioned type Ambroz 16/4.III, and a bronze bracelet of the Roman tradition (Fig. 25.6:1). ${ }^{73}$ Before complete publication of the site, any interpretation of these finds will remain preliminary. Quite plausibly, these are graves of military settlers of barbarian origin, as Italian scholars have suggested. In any case, their assimilation (acculturation), according to the evidence of the grave goods and grave types, was quite advanced.

It is important to note a pair of small radiate-headed brooches of the Chernyakhiv tradition, of type Ambroz 1AA and allegedly from the vicinity of Varese Lake, Varese district in northern Italy, from I. von Diergardt's collection. They are made of silver, covered with gold foil and decorated with isolated garnets, and measure $7.7 \mathrm{~cm}$ in length (Fig. 25.6:4). According to J. Werner, the Italian origin of these brooches is an apocryphal. ${ }^{74}$ In fact, all the parallels to small radiate-headed brooches of the Chernyakhiv tradition with

69 Sannazaro 2006.

70 See Sannazaro 2006, 63, fig. 2.

71 See for example: Ambroz 1966, 70, 71; Schultze 1977, 14-16.

72 See Sannazaro 2006, 61-63, fig. 1. The preliminary publication of 2006 confuses illustration numbers 1 and 4 . This error also occurs in my previous publications, such as Kazanski 2012.

73 See Sannazaro 2006, 64-67, fig. 4; 5 .

74 Werner 1961, 26, tab. 19.87 . 

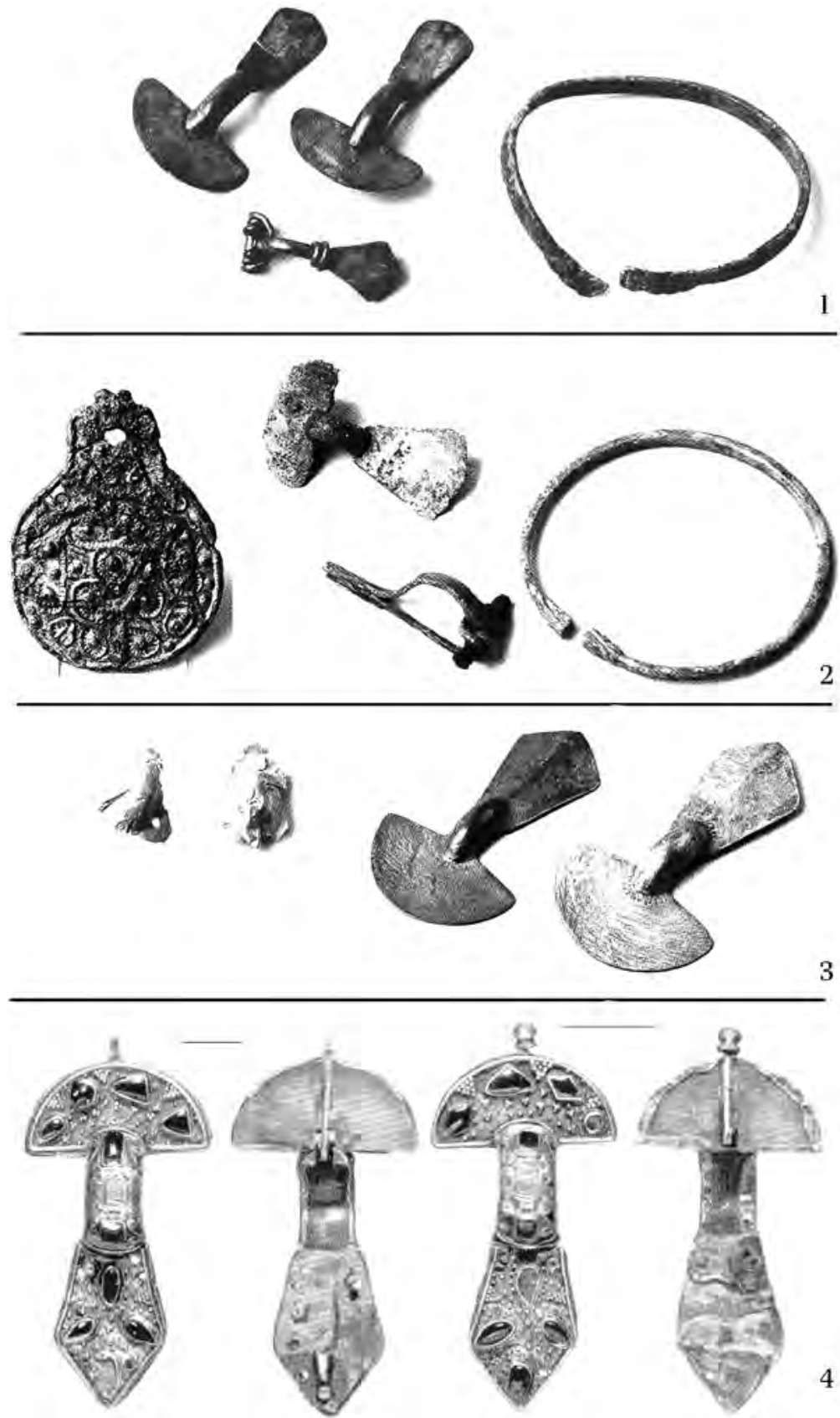

FIGURE 25.6 East Germanic artefacts from Italy: 1 - Sacca di Goito, grave 215; 2 - Sacca di Goito, grave 210; 3 - Sacca di Goito, Mantova district, grave 206; 4 - Varese, Varese district (1-3 after: Sannazaro 2006; 4 after: Werner 1961) 
polychrome decoration known to me originate not from the Roman West, but the Cimmerian Bosphorus. ${ }^{75}$

The territory which is now southern Germany, where a few Late Chernyakhiv artefacts are known, formed a part of the Roman province of Raetia. No presence of Goths as a specific group in the area is documented by written sources, and so rare finds of artefacts of interest should rather reflect the appearance of relatively small barbarian groups or individuals of eastern European origin. Among these finds are combs of type Thomas III (Fig. 25.7:1-6). Some of these were found in forts, perhaps because natives of eastern Europe served in the Roman garrisons there. ${ }^{76}$

A grave at Götting, Bad-Aibling district (Germany), in Upper Bavaria, supplies evidence of some Post-Chernyakhiv traditions there. ${ }^{77}$ It contained a radiate-headed brooch, a derivative of brooches of type Ambroz ІвА, a comb with a triangular back of type Thomas II, of a Roman tradition, and a grey ceramic wheel-thrown vessel resembling Chernyakhiv vases (Fig. 25.7:7-9). That vessel could also have derived from a Roman tradition, however, as did all the Chernyakhiv pottery. The symbol scratched on the foot-plate of a brooch resembles Later Roman engraved designs on soldier's belts. ${ }^{78}$

In case of Britain, well-studied archaeologically, we actually have only two finds of brooches of the Chernyakhiv tradition. Firstly, there is a crossbow brooch with returned foot from Saint Albans, county of Hertfordshire (England), north of London (Fig. 25.8:1), with a flaring triangular foot-plate of the already mentioned type Ambroz 16/4-III. ${ }^{79}$ Although its connection with the Chernyakhiv Culture is obvious, the chronological range of this type is wider than the early stage of the Migration Period discussed here, enveloping the Later Roman Period too.

The second brooch was discovered in the famous hoard of Traprain Law, East Lothian, in southern Scotland, east of Edinburgh, north of Hadrian's Wall. The latest coin in the hoard is of to Honorius. ${ }^{80}$ It has been thought that the hoard belonged to a local chief who established, in one way or another, a political connection with the Empire. The hoard contained a small radiateheaded brooch (Fig. 25.8:3), most likely an imitation of the Chernyakhiv type

Shchukin, Kazanski, Sharov 2006, fig. 161.17; 165.10.

76 Schwarz 1972-1973, fig. 23.1; Keller 1979, tab. 12.5; Fischer, Spindler 1984, fig. 71, 1, 2; Kühn 1974, fig. 93 .

78 E.g. Böhme 1974b, tab. 94.13, 108.3, 120.11.

79 Böhme 1986b, 49o, fig. 15·3.

80 Curle 1923. 

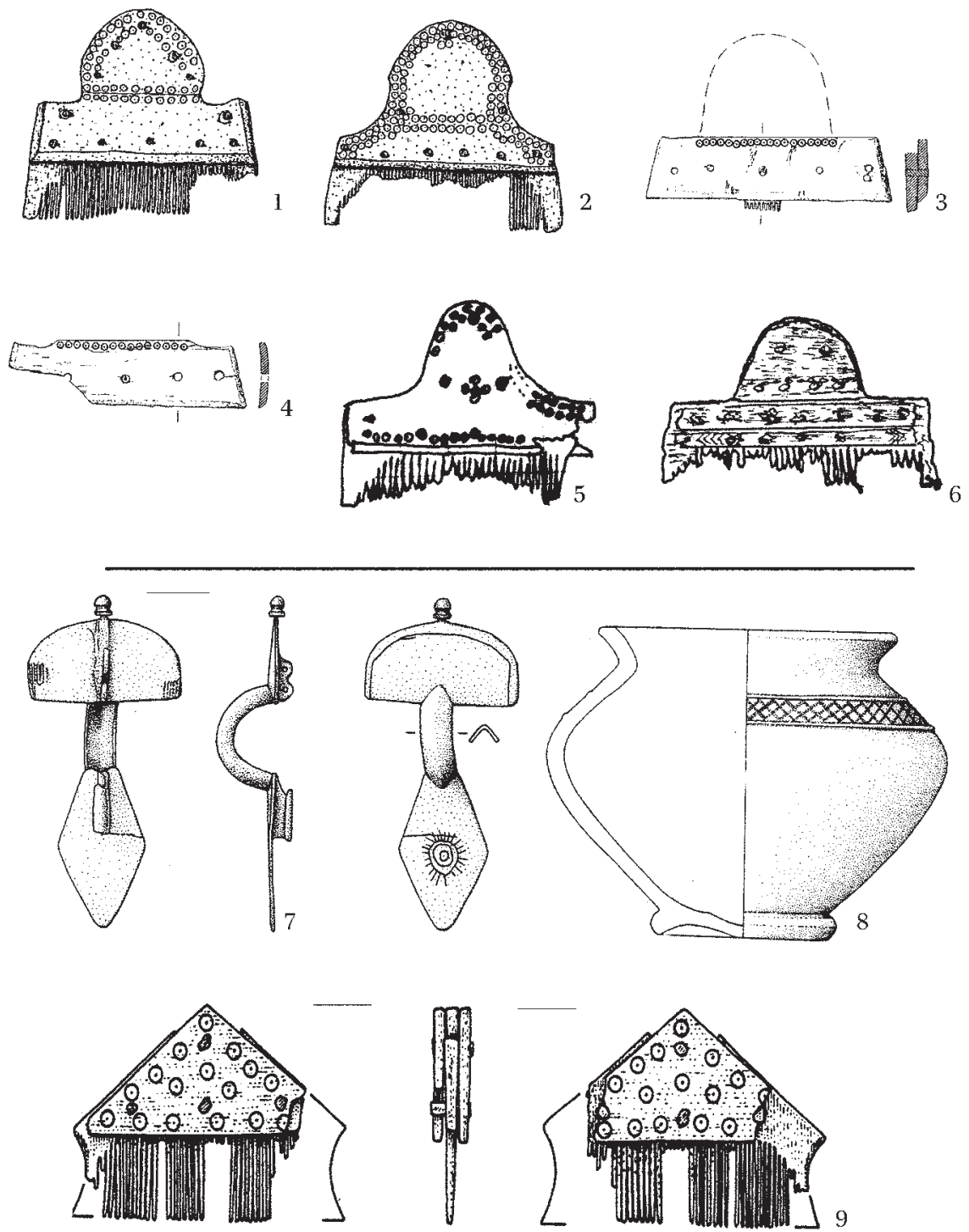

FIGURE 25.7 East Germanic artefacts from Raetia: 1, 2-Abusina-Eining, Niederbayern district; 3, 4-Regensburg-Niedermünster, Oberpfalz district; 5 - Neuburgan-der-Donau-Stadtberg, Oberbayern district; 6 - Gross-Umstadt, Hessen district; 7-9 - Götting, Bad-Aibling district (1, 2 after: Fischer, Spindler 1984; 3, 4 after: Schwarz 1972-1973; 5 after: Keller 1979; 6 after: Kühn 1974; 7-9 after: Keller 1971) 
Ambroz 1 АБ. ${ }^{81}$ Finally, we should also mention grave B1 of the cemetery at Kingsholm, Gloucester, Gloucestershire (England) in which were found, inter alia, shoe-fittings with silver buckles and two strap-ends (Fig. 25.8:9-12). ${ }^{82}$ This type of strap-end is typical of Pontic and Danubian mounts of AlanoSarmatian origin. ${ }^{83}$

Thus the artefacts of the East Germanic and Alano-Sarmatian tradition which were known in the Roman West during the Age of Migrations were concentrated mostly in Gaul and Spain. Nowadays it is difficult to determine if this is a reflection of the true historical situation or is related to our present level of archaeological information. Women's artefacts are more informative because, as already noted, they, in contrast to men's goods, were of an "ethnographical" nature. There is one case of osteological analysis (Angers) which shows categorically that persons buried with the Chernyakhiv artefacts had features distinguishing them from the mass of the Gallo-Roman population.

The artefacts of interest here are scattered in space and do not form any territorial cluster, except in the Rhine basin and in Aquitania. One may suppose that these zones of concentration are related to particular historical processes, such as the participation of the barbarians in the defence of the Rhine limes, and the settling of Goths in the occupied lands of southern Gaul. East Germanic and Alano-Sarmatian artefacts usually appear at Roman sites and in the context of the Roman culture, which indicates a relatively high degree of integration into Roman society. It is important to notice several cases in which Sarmato-Alanic goods appear in the same complex (Reims, Troyes, Sacca di Goito), which indicates the probability of symbiosis of groups of East Germanic and Iranian-speaking barbarians. These groups could possibly have forged a certain unity before they came to the Imperial territory, for example within joint armies of barbarians, such as the huge force of Radagaisus. ${ }^{84,85}$

81 Curle 1923, pl. 32.145; Böhme 1986b, 491, fig. 15.2. It is interesting that the knobbed decoration on the brooch from Traprain Law finds parallels located far to the east, on a brooch of the Chernyakhiv tradition from the cemetery of Baital-Chapkan, Republic of Karachayevo-Cherkessia (Russia), in the northern Caucasus (see Mastykova 2009, 50, 51).

82 See Böhme 1986b, 503, fig. 25 .

83 Kazanski, Akhmedov 2007, 255, 256.

84 Kazanski 2012.

85 Michel Kazanski, French National Centre for Scientific Research (CNRS), Paris, France. 

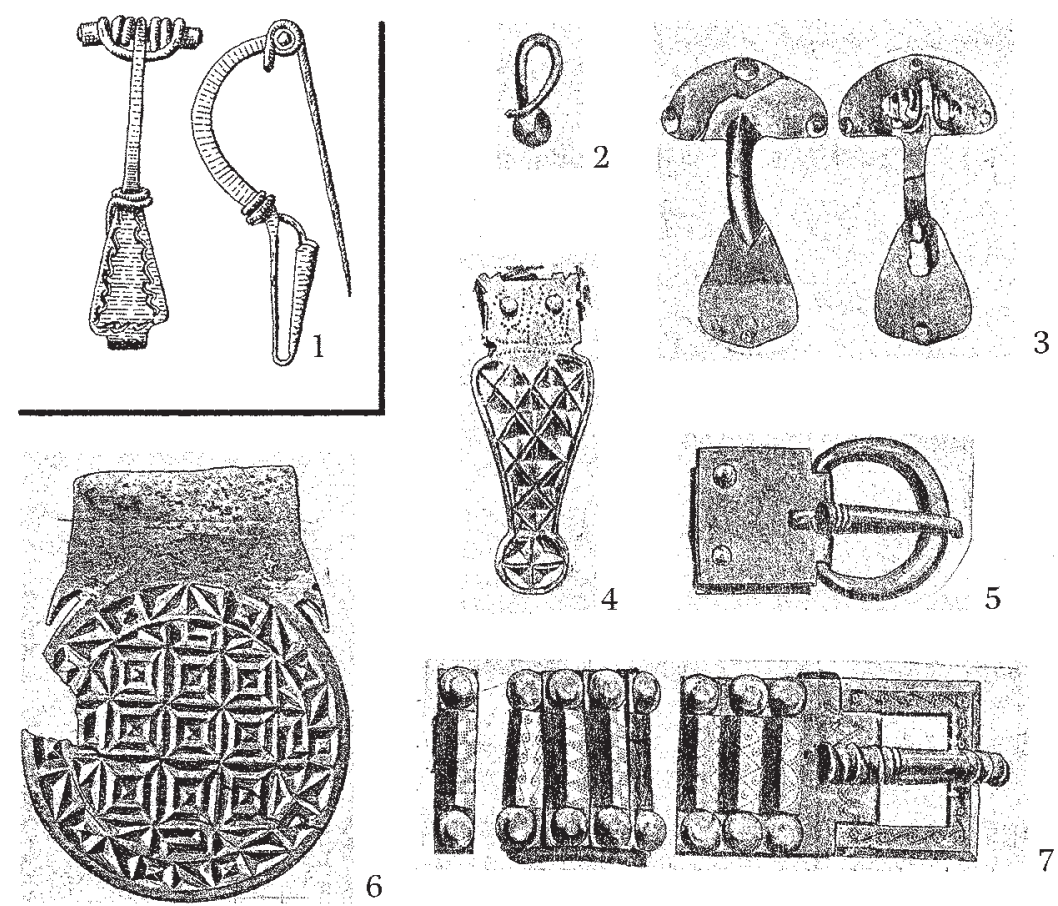

6
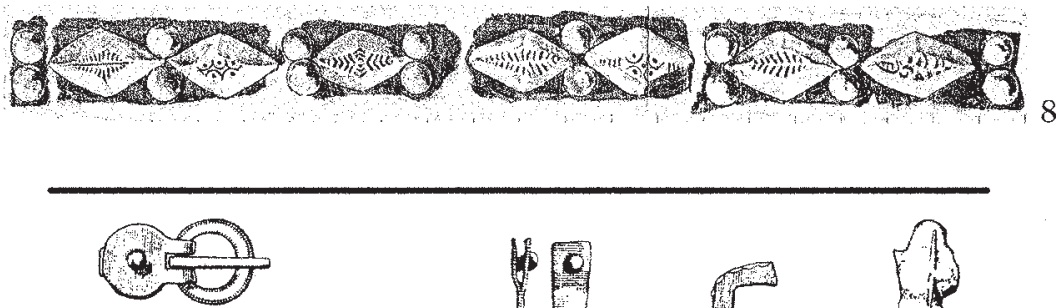

$=-29$
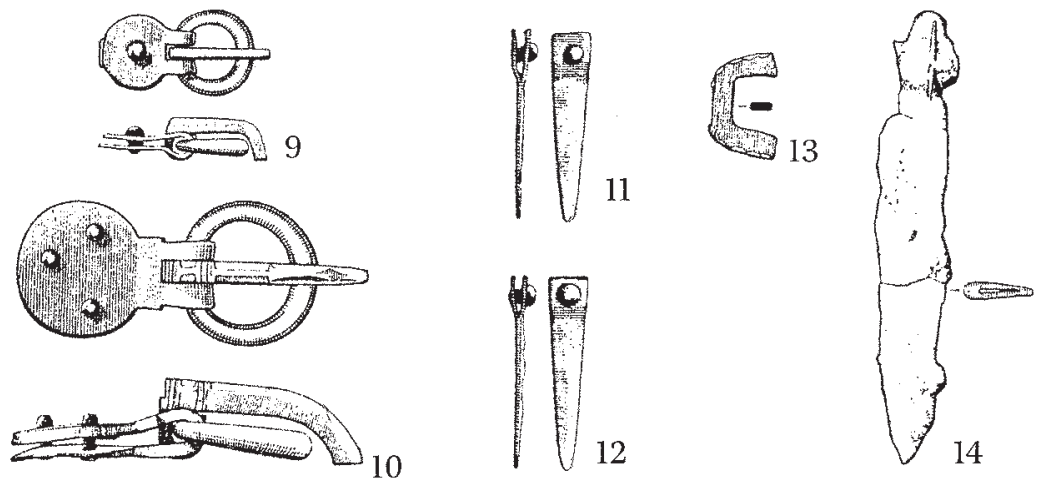

FIGURE 25.8 Chernyakhiv brooches and some associated finds from Britain: 1 - Saint Albans, Hertfordshire; 2-8 - Traprain Law, East Lothian; 9-14 - Kingsholm, Gloucester, Gloucestershire, grave B1 (1, 9-14 after: Böhme 1986b; 2-8 after: Curle 1923) 